\title{
High resolution magnetic, regional gravity and petrophysical characterization of the Dominican Republic tectonic domains with special focus on the Central Cordillera
}

\author{
C. Ayala ${ }^{(1,2)}$, J. L. García-Lobón ${ }^{(1)}$, J. Escuder-Viruete ${ }^{(1)}$, C. Rey-Moral ${ }^{(1)}$, A. Pérez-Estaún ${ }^{(3,+)}$ y A. Padín-Debén ${ }^{(4)}$
}

(1) Geological Survey of Spain (IGME), C/ La Calera n. 1, 28760 Tres Cantos, Madrid. Tl.: +34 917287218, Fax: +34 917287202 c.ayala@igme.es; jl.garcia@igme.es; j.escuder@igme.es; c.rey@igme.es

(2) Now visiting at the Institute of Earth Sciences Jaume Almera-CSIC, C/ Lluís Solé i Sabarís s/n, 08028 Barcelona.

(3) Institute of Earth Sciences Jaume Almera, C/ Lluís Solé i Sabarís s/n, 08028 Barcelona. Fallecido el 13 de agosto de 2014.

(4) Basalt Energy. Avda. del Ejército 16, 1C, 15006 A Coruña.

apadin@basaltenergy.net

\begin{abstract}
The aim of this study is twofold: to make a geological interpretation of available ground gravity and high resolution airborne magnetic surveys carried out over the Dominican Republic, and to define the spatial limits of key tectonic units of the Central Cordillera. Potential fields and petrophysical data allow the establishment of the spatial limits and the relationships of the key tectonic units at local and regional scale. Therefore, gravity and magnetic data have been integrated to produce models of the upper crustal structure across the Central Cordillera following corresponding geological cross-sections that have been extended in depth. Since there are no seismic or borehole data to constrain the models in our study area, modelling is based on potential field data and the analysis of the physical properties that have been measured from surface rocks (586 density and magnetic susceptibility samples). The main features of the potential fields maps are: (1) NW-SE-trending anomalies delineating the main tectonic units, which coincide with the major strike-slip fault zones that limit those units; (2) exceptional geophysical mapping examples of volcano-sedimentary units; and (3) significant anomalies due to a magmatism widely spread all over Hispaniola Island. The modelling results reveal the petrophysical heterogeneities and subsurface geometry of the tectonic units, faults and shear zones. The model shows that Tireo Fm extends up to $7 \mathrm{~km}$ in depth. The Duarte Complex has been modelled as a layer of c. 5-7 km in thickness beneath the Tireo Fm and the S. Juan Basin. Some of the intrusive bodies may reach depths of c. $8 \mathrm{~km}$.
\end{abstract}

Key words: Central Cordillera-Dominican Republic, Density, Geophysical mapping, Magnetic susceptibility, Potential field modelling.

\section{Caracterización de los dominios tectónicos de la República dominicana, con especial énfasis en la Cordillera Central, mediante datos aeromagnéticos de alta resolución, gravimetría regional y petrofísica}

\author{
RESUMEN
}

El objetivo de este estudio es doble: realizar una interpretación geológica de los datos de gravedad y aeromagnetismo de alta resolución disponibles en la República Dominicana, y definir los límites espaciales de las principales unidades tectónicas de la Cordillera Central. Los datos geofísicos de campos potenciales junto con datos petrofísicos permiten establecer los límites espaciales y las relaciones entre las unidades tectónicas más importantes tanto a escala local como regional; dichos datos se han integrado para obtener modelos de la corteza superior de la Cordillera Central a lo largo de dos cortes geológicos extendidos en profundidad. Como no existen datos sísmicos o de sondeos, la modelización se basa en la interpretación cuantitativa de los campos potenciales y los datos petrofísicos de muestras recogidas para tal fin (586 medidas de densidad y susceptibilidad magnética). 
Ayala, C., et al., 2017. High resolution magnetic, regional gravity and petrophysical... Boletín Geológico y Minero, 128 (3): $611-631$

Las características principales de los mapas de campos potenciales son: (1) Anomalías en dirección NOSE que definen las principales unidades tectónicas coincidiendo con las zonas de falla de desgarre que las delimitan; (2) excepcionales ejemplos de cartografía geofísica de las unidades volcanosedimentarias y (3) importantes anomalías debidas al magmatismo que ocupa gran parte de la isla de La Hispaniola. Los resultados de la modelización muestran las heterogeneidades petrofísicas y la geometría en profundidad de las unidades tectónicas, zonas de falla y de cizalla. La modelización muestra que la Fm. Tireo se extiende hasta $7 \mathrm{~km}$ de profundidad y que el Complejo Duarte es una capa de 5 a $7 \mathrm{~km}$ de espesor bajo la Fm. Tireo y la cuenca de San Juan. Algunos batolitos llegan a alcanzar profundidades de $8 \mathrm{~km}$.

Palabras clave: Cartografía geofísica, Cordillera Central-República Dominicana, Densidad, Susceptibilidad magnética, Modelización de campos potenciales.

\section{VERSIÓN ABREVIADA EN CASTELLANO}

\section{Introducción}

La isla de La Española, que comprende República Dominicana y Haití, está situada en el margen norte de la Placa del Caribe (Fig. 1). La Española incluye el registro más completo de la historia geológica de la Placa del Caribe desde el Jurásico hasta el Presente (e.g. Mann et al., 1991, 1995). La evolución tectónica reciente de la isla ha dado lugar a una morfología caracterizada por una alternancia de montañas y valles. La isla presenta un marco tectónico complejo con muchas incertidumbres, que pueden ser abordadas mediante la interpretación de campos potenciales.

En 1995-96, bajo los auspicios del proyecto SYSMIN (SYstem for Safeguarding and developing MINeral production, financiado por la UE para el desarrollo geológico y minero de la República Dominicana) se llevó a cabo un vuelo magnético y radiométrico de alta resolución cuya interpretación como apoyo a la cartografía geológica y la prospección minera se realizó en el marco de diversos subproyectos entre 1997 y 2004 (ver García-Lobón y Rey-Moral 2002a and b, and García-Lobón y Ayala, 2005)

El objetivo de este trabajo es estudiar la estructura profunda de los dominios tectónicos de la Cordillera Central ampliando las interpretaciones preliminares de Garcia-Lobón and Ayala (2007). Dado que no hay datos sísmicos o de sondeos, la integración de datos magnéticos y gravimétricos, junto con el conocimiento de la geología de superficie y el análisis petrofísico de muestras de las principales litologías permite establecer los límites espaciales de sus unidades tectónicas más relevantes, tanto a escala local como regional, y las relaciones entre ellos. Se han construido dos modelos de la corteza superior que cruzan la Cordillera Central en dirección NO-SE basados en la modelización de campos potenciales y petrofísica. Dichos modelos muestran las relaciones entre litologías, su geometría y propiedades físicas a nivel de basamento y la geometría de las zonas de cizalla y de falla.

\section{Contexto geológico}

La geología de La Hispaniola está formada por un collage tectónico $250 \mathrm{~km}$ de ancho que contiene rocas ígneas, metamórficas y volcano-sedimentarias de edades comprendidas entre el Jurásico Superior-Cretácico Inferior hasta el Eoceno Medio formadas y acretadas en un contexto intraoceánico de arco de isla (Bowin, 1975; Lewis and Draper, 1990; Mann et al., 1991, 1995). Durante el Eoceno y el Neógeno, estos terrenos derivados del arco de islas fueron yuxtapuestos a lo largo de zonas de cizalla de dirección ONO-OSE debido a la colisión oblicua del arco con la placa de Norte América a lo largo de la Plataforma de las Bahamas. Estas fallas son, de $\mathrm{N}$ a S: Septentrional (SFZ), Hispaniola (HFZ), Bonao-La Guácara (BGFZ), San Juan-Restauración (SJRFZ) y Enriquillo-Plantain Garden (EPGFZ) (Mann et al., 1991).

La estructura más importante de la isla es la HFZ (Fig. 2), una falla de desgarre que cruza toda la isla con un importante desplazamiento lateral que pone en contacto dos fragmentos de corteza distintos: el arco de isla primitivo del Cretácico Inferior y la parte sur del plateau oceánico del Complejo Duarte y el arco de islas del Cretácico Superior de la Fm. Tireo.

El presente estudio se centra en los dominios tectónicos de la Cordillera Central, limitados al norte por la HFZ y al sur por la SJRFZ (Figs. 2 y 3). Comprende una gruesa secuencia magmática del Jurásico SuperiorCretácico Superior que incluye una gran variedad de rocas plutónicas, volcánicas, volcanoclásticas y sedimentarias (pe. Escuder-Viruete et al., 2006-a, 2007). Estas rocas fueron deformadas y, en el caso de Duarte Complex, metamorfizadas a facies de esquistos verdes y anfibolitas. Los cuatro dominios tectónicos en los que se divide la Cordillera Central se muestran en la Fig. 3. 
Ayala, C., et al., 2017. High resolution magnetic, regional gravity and petrophysical... Boletín Geológico y Minero, 128 (3): $611-631$

\section{Datos geofísicos, petrofísica y modelización 2.5D}

Los datos aeromagnéticos (Fig. 4) y gravimétricos (anomalía de Bouguer, Fig. 5) se correlacionan con las principales unidades tectónicas y definen las zonas de desgarre que las delimitan. Los datos aeromagnéticos, además, permiten cartografiar con precisión las rocas magmáticas aflorantes o subaflorantes que se encuentran repartidas por toda la isla.

Los datos petrofísicos, provenientes del análisis de 586 muestras, se han utilizado para caracterizar la densidad y susceptibilidad magnética de las distintas litologías, datos que se han incorporado en la modelización (Tabla I).

En la Cordillera Central se han realizado dos modelos 2.5D utilizando los datos magnéticos reducidos al polo y la anomalía de Bouguer residual (Fig. 6A y 6B) con el objetivo de caracterizar en profundidad los límites laterales de los dominios tectónicos, la naturaleza del basamento y la distribución de densidades y susceptibilidades magnéticas en la corteza superior (Figs. 7,8 y 9).

\section{Resultados}

Los resultados de la modelización muestran que la Fm. Tireo tiene un espesor entre 3 y 7 km y está plegada y atravesada por cuerpos intrusivos de magnetización variable. Estos cuerpos llegar hasta $7.5 \mathrm{~km}$ de profundidad, alcanzando el techo del Complejo Duarte, una capa heterogénea de 5 a $7 \mathrm{~km}$ de espesor que se extiende desde la HFZ en el norte hasta debajo de la cuenca de San Juan, en el sur. Los sedimentos en la cuenca de Cibao alcanzan los $6.5 \mathrm{~km}$ de profundidad y en la de San Juan, cerca de $6 \mathrm{~km}$. La HFZ alcanza una profundidad mínima de $11 \mathrm{~km}$, alcanzando la base de la corteza superior. La modelización no muestra la existencia de despegues: secuencias geológicas de distinto origen como el Complejo Duarte y la Fm. Tireo aparecen plegados conjuntamente sin que se evidencien discontinuidades a gran escala en profundidad.

\section{Conclusiones}

- El análisis petrofísico de las muestras ha permitido caracterizar la densidad y susceptibilidad magnética de los principales dominios tectónicos de la República Dominicana, en particular en la Cordillera Central. Las densidades varían entre $2.31 \mathrm{Mg} / \mathrm{m} 3$ de las pizarras hasta $3.18 \mathrm{Mg} / \mathrm{m} 3$ de las eclogitas y la susceptibilidad magnética oscila entre 2x10-5 SI para los tuffs ácidos hasta 10979×10-5 SI para las rocas ultrabásicas, reflejando la complejidad del marco tectónico. Debido a que no se dispone de datos de sísmica ni de sondeos para restringir los modelos, los datos petrofísicos son fundamentales en la modelización.

- Diferencias en la fábrica magnética se pueden correlacionar con la composición geoquímica lo que sugiere que distintos dominios corticales en la Cordillera Central fueron parte de diferentes dominios corticales del arco de islas cretácico del Caribe, que inicialmente se formaron aparte y más tarde se yuxtapusieron como resultado del régimen tectónico transpresivo desde la colisión arco-continente (Eoceno Medio).

- En los datos magnéticos se pueden identificar cinco dominios, que se correlacionan con los dominios estructurales y están delimitados por las zonas de falla más importantes. El límite tectónico más importante es la HFZ que separa la Cordillera Central (cuyo basamento es el Complejo Duarte) de la cuenca del Cibao (cuyo basamento es la Fm. Amina).

- Las rocas metavolcánicas de composición entre máfica y félsica de la Fm. Amina tienen una composición, fábrica estructural e historia geológica distinta respecto a las del complejo Duarte. Por ello, el Complejo Duarte está caracterizado por anomalías magnéticas de longitud de onda corta mientras que la cuenca del Cibao presenta una respuesta magnética constante. Los cortes geológicos modelizados que atraviesan la Cordillera Central no muestran la existencia de zonas de despegue, como en otras zonas deformadas por transpresión. En este caso, secuencias geológicas de origen distinto como el Complejo duarte y la Fm. Tireo están plegadas conjuntamente sin la presencia de discontinuidades a gran escala en profundidad.

- El patrón de las anomalías magnéticas en la Cordillera Central se debe a la interferencia entre: (1) anomalías de longitud de onda intermedia-larga causadas por el basamento magnéticamente heterogéneo con una susceptibilidad bimodal del Complejo Duarte, más el efecto del carácter paramagnético de las cuencas Cibao y San Juan; (2) anomalías de longitud de onda corta debidas a las variaciones laterales de susceptibilidad de las rocas volcanosedimentarias de la Fm. Tireo, las rocas intrusivas del batolito de Loma Cabrera y complejos asociados (profundidades entre 6 y $8 \mathrm{~km}$ ).

- Los resultados de la modelización muestran las heterogeneidades petrofísicas de las distintas litologías atravesadas por los perfiles y la geometría en profundidad de los contactos entre las unidades tectónicas, las fallas y zonas de cizalla. Dichos resultados sugieren que el plegamiento Eoceno que afectó a la Fm. Tireo afectó también a basamento del Complejo Duarte y este evento junto con los cambios de tempera- 
Ayala, C., et al., 2017. High resolution magnetic, regional gravity and petrophysical... Boletín Geológico y Minero, 128 (3): $611-631$

tura ocurridos durante el emplazamiento del batolito de Loma Cabrera pueden haber modificado su carácter magnético. Estos modelos corticales contribuyen a incrementar nuestro conocimiento sobre la arquitectura de la Cordillera Central y su evolución tectónica desde el Mesozoico.

\section{Introduction}

The Island of Hispaniola, that comprises the Dominican Republic and Haiti, is located at the northern margin of the Caribbean Plate (Fig. 1). Hispaniola includes the most complete records of the geological history of the Caribbean Plate from Jurassic to Present (e. g. Mann et al., 1991, 1995). The recent tectonic evolution of Hispaniola has given rise to a morphology characterized by alternating ranges and valleys.

The Hispaniola Island deformed under a transpressional regime (which has been active since early Cenozoic times) due to the oblique convergence of the Caribbean island arc and the North American con- tinental margin (Mann et al., 2002; Escuder Viruete et al., 2006-a; Perez-Estaun et al., 2007). Within the transpressional regimes, levels of detachments could be present at depth in crustal cross-sections and, on the surface, deformation may be partitioned into discrete, steeply dipping shear zones that separate broader domains with folds and thrusts, evidencing normal shortening and vertical, lateral or oblique extension (Dewey et al., 1998). In this complex tectonic setting, potential field data helps us to approach these uncertainties in two ways: (1) the aeromagnetic map has been an aid in the geological mapping and together with the Bouguer anomaly, have been used to constrain the surface and subsurface distribution of different crustal domains with specific magnetic proper-

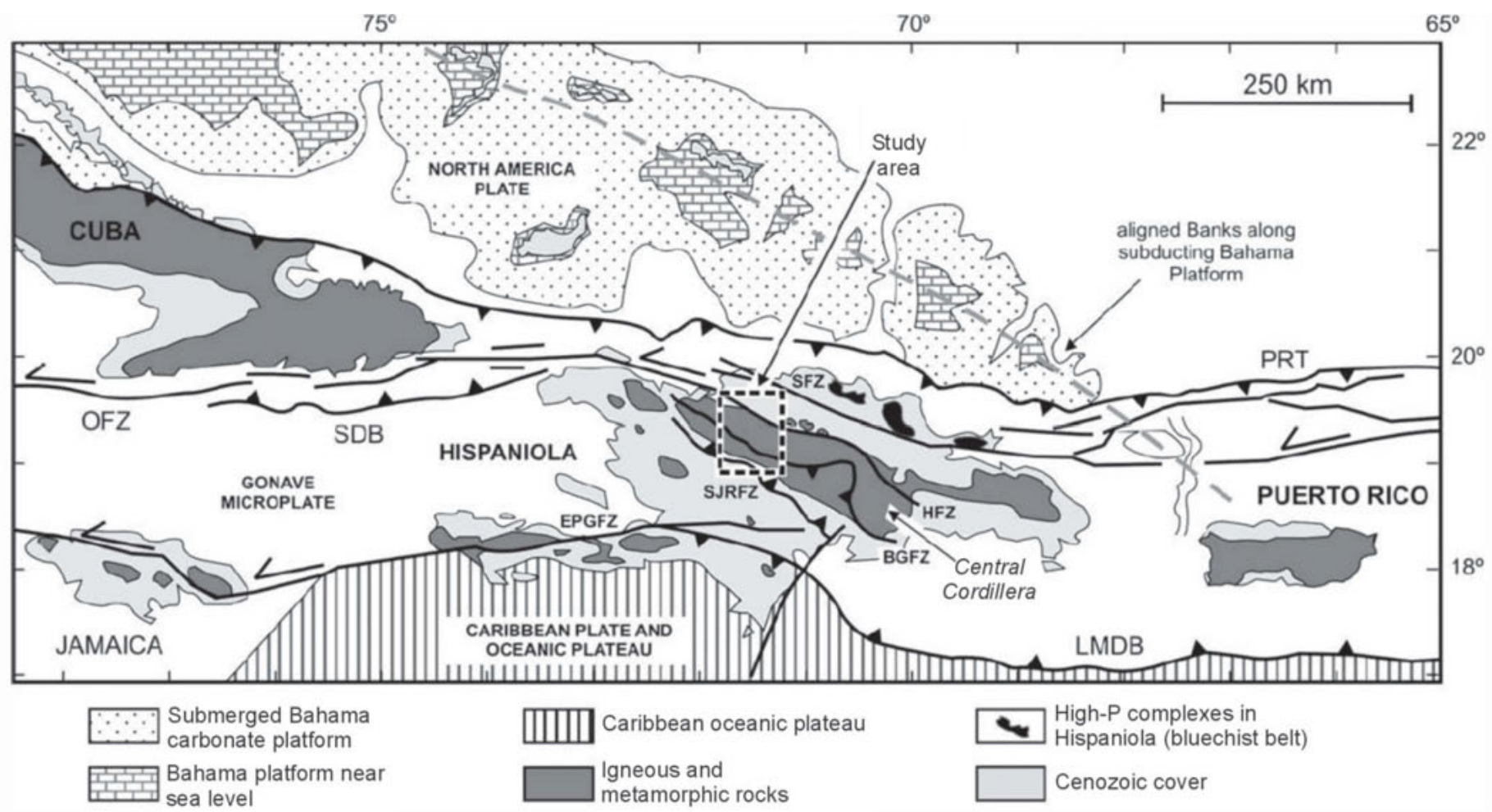

Figure 1. Tectonic map of the Northeastern Caribbean Plate margin modified from Dolan et al. (1998) and Escuder-Viruete et al., (2006) showing major fault zones: OFZ, Oriental Fault Zone; SDB, Santiago deformed belt; EPGFZ, Enriquillo-Plantain Garden Fault Zone; SFZ, Septentrional Fault Zone; HFZ, Hispaniola Fault Zone; BGFZ, Bonao-La Guácara Fault Zone; SJRFZ, San Juan Restauración Fault Zone; PRT, Puerto RicoTrench; LMDB, Los Muertos deformed belt. The study area corresponding to the potential fields shown in Figure 6 which is outlined with a dashed rectangle.

Figura 1. Mapa tectónico del margen septentrional de la Placa del Caribe modificado de Dolan et al. (1998) y Escuder-Viruete et al., (2006) mostrando las principales zonas de falla: OFZ, Zona de Falla Oriental; SDB, cinturón deformado de Santiago; EPGFZ, Zona de Falla de Enriquillo-Plantain Garden; SFZ, Zona de Falla Septentrional; HFZ, Zona de Falla de La Española; BGFZ, Zona de Falla de Bonao-La Guácara; SJRFZ, Zona de Falla de San Juan-Restauración; PRT, Fosa de Puerto Rico; LMDB, cinturón deformado de Los Muertos. El área estudiada se corresponde con los campos potenciales mostrados en la Figura 6 y está marcada con un rectángulo de líneas discontinua. 
Ayala, C., et al., 2017. High resolution magnetic, regional gravity and petrophysical... Boletín Geológico y Minero, 128 (3): $611-631$

ties at the surface, thus helping to identify the $\mathrm{km}$ scale structures, and (2) structures at depth, based on geological cross-sections, could be constrained with the interpretation and modelling of potential field anomalies. In particular, potential field data may help identify major features in basements covered by sedimentary sequences.

In 1995-96, within the frame of the SYSMIN project (SYstem for Safeguarding and developing MINeral production, funded by the European Union for the mining and geological development of the Dominican Republic), a high resolution magnetic and radiometric survey was flown over the Dominican Republic. Several geological mapping and mineral resources research projects have also been recently completed (termed C, K and L, 1997-2004; the geological interpretation within these projects has been supported by the high-resolution flights; see García-Lobón and ReyMoral 2002a and b, and García-Lobón and Ayala, 2005). During the $C, K$ and L projects, 586 rock samples were collected and analysed to obtain density and magnetic susceptibility values, mainly from igneous and metamorphic rocks within the central part of Hispaniola.

Our investigation focuses on the Central Cordillera, where the study of the deep structure of the tectonic domains expands the preliminary interpretation made by Garcia-Lobón and Ayala (2007) based on gravity and magnetic data. No seismic experiments have ever been carried out in our study area. The only existing seismic data that have been published (Electroconsult, 1981; Mann and Lawrence, 1991) was acquired in selected areas of the Cibao basin and the San Juan and Enriquillo basins for oil exploration, and are located far away from our modelled profiles. Given that the basement structure has not been imaged by seismic data, it is not possible to establish a correlation between the basement to the south and the basement being modelled with potential fields further north. Given that there is no borehole data either, the integration of magnetic and gravity images, together with the increasing knowledge of the surface geology and the petrophysical analysis of samples from the main lithologies of the Dominican Republic, allows us to set the spatial limits of key tectonic units, both at local and regional scale, and the relationships between them. Based on the potential field data, two models crossing the Central Cordillera in the SW-NE direction have been elaborated to display the upper crustal structure and the variation with depth of the properties of these tectonic units. The models reveal relationships between the lithologies and delineate the depth geometry of shear zones and faults.

\section{Geological setting}

Hispaniola's geology consists of a $250 \mathrm{~km}$ wide tectonic collage of fault-bounded igneous, metamorphic and volcano-sedimentary rocks of Late Jurassic-Early Cretaceous to Middle Eocene age, that had been formed and accreted in an intra-oceanic island-arc setting (Bowin, 1975; Lewis and Draper, 1990; Mann et al., 1991, 1995). During the Eocene and along the Neogene these island-arc derived terranes were juxtaposed along WNW-WSE-trending strike-slip fault zones, due to the oblique collision of the arc with the North American Plate along the Bahama Platform. These fault zones are, from $\mathrm{N}$ to $\mathrm{S}$ : Septentrional (SFZ), Hispaniola (HFZ), Bonao-La Guácara (BGFZ), San Juan-Restauración (SJRFZ) and EnriquilloPlantain Garden (EPGFZ) (Mann et al., 1991). Rocks of the involved tectonic units are partially covered by Eocene to Pliocene and recent siliciclastic and carbonate sedimentary rocks that post-date island-arc activity and mainly record the initiation of the present period of left-lateral strike-slip motion coeval with active subduction in the southern Hispaniola margin (Dolan et al., 1998; Mann, 1999). As a consequence of the Eocene collision and sinistral transcurrent tectonics the structure of the island arc has been substantially modified.

The significant structure of the island is the HFZ (Fig. 2). This is a large-scale strike-slip fault with an important lateral displacement that puts in contact two different crustal fragments: the northerly Lower Cretaceous primitive island arc from the southern Duarte Complex oceanic plateau and the Upper Cretaceous island-arc sequence of the Tireo Formation $(\mathrm{Fm})$. Loma Caribe serpentinized peridotites crop out along this fault zone.

From north to south, the following tectonic domains can be distinguished in the Dominican Republic (Fig. 2):

- North of Camú Fault Zone (CFZ), a subduction complex, exhumed during the collision between the Caribbean island arc and the Bahamas carbonate platform, which includes high-P rocks of Puerto Plata, Río San Juan, and Samaná complexes (e.g., Nagle 1974, Draper and Nagle, 1991; Gonçalves et al., 2000; Escuder Viruete et al., 2006-c; Krebs et al., 2008) that consist of amphibolites, gabbros, eclogites, mafic schists and gneiss assemblages.

- The Mamey Group (De Zoeten and Mann, 1999) comprise all the Upper Eocene to Lower Miocene sedimentary rocks in the Septentrional Cordillera. This group includes turbiditic units, and is located between the CFZ and the Septentrional fault zone (SFZ). The CFZ and SFZ are of special importance 


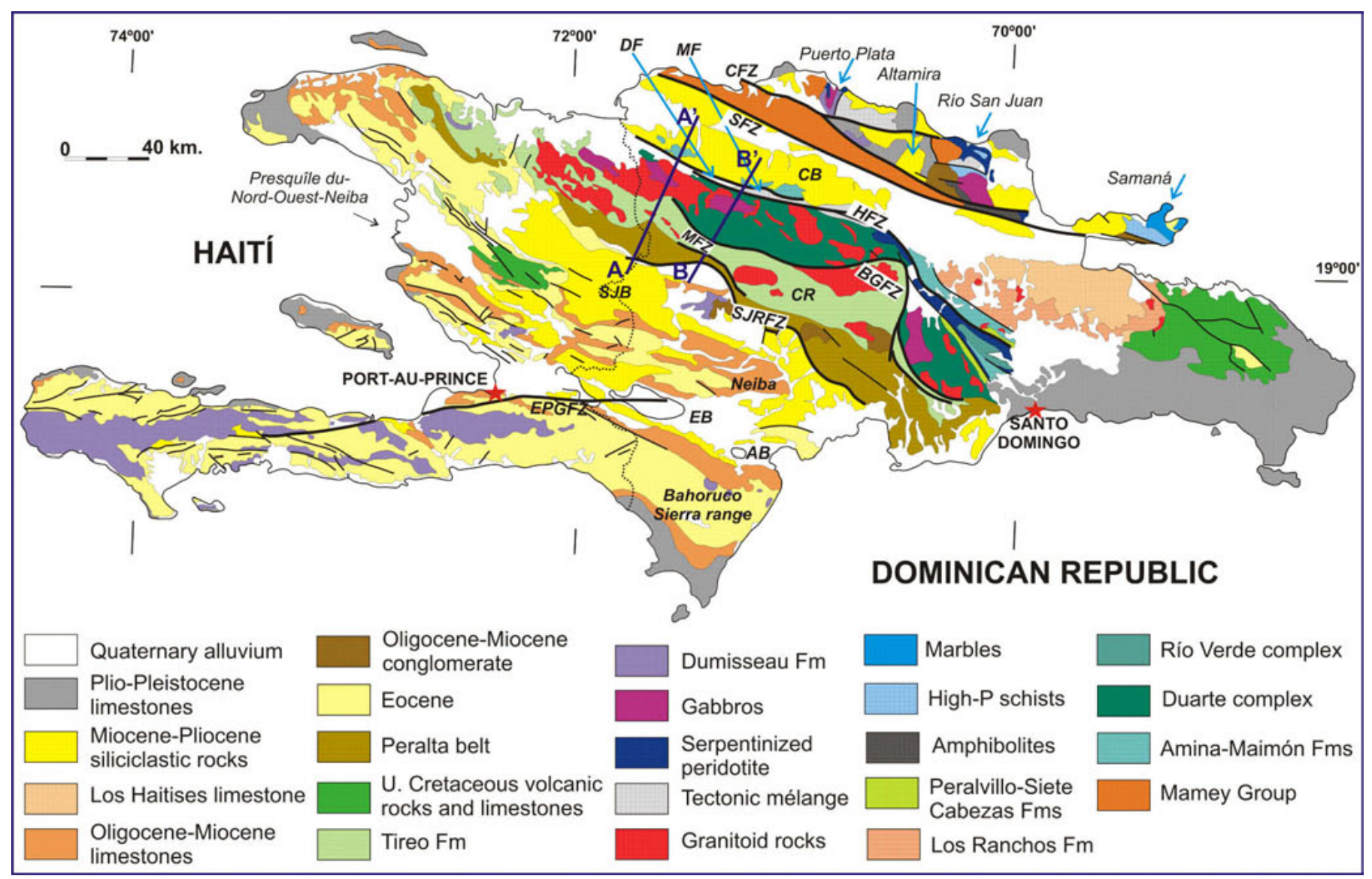

Figure 2. Geological map of Hispaniola Island (modified from Draper and Lewis, 1991). CFZ: Camú Fault Zone; SFZ: Septentrional Fault Zone; HFZ: Hispaniola Fault Zone; BGFZ: Bonao-La Guácara Fault Zone; MFZ: Macutico Fault Zone; SJRFZ: San Juan Restauración Fault Zone; EPGFZ: Enriquillo-Plantain Garden Fault Zone; DF: Djabon Formation; MF: Magua Formation; CB: Civao Basin; CR.: Central Cordillera; SJB: San Juan Basin; EB: Enriquillo Basin; AB: Azua Basin. Blue lines labelled AA' and BB': location of the modelled profiles. Figura 2. Mapa Geológico simplificado de la isla de La Española (modificado de Draper y Lewis, 1991). CFZ: Zona de Falla de Camú; SFZ: Zona de Falla Septentrional; HFZ: Zona de Falla de La Española; BGFZ: Zona de Falla Bonao-La Guácara; MFZ: Zona de Falla Macutico; SJRFZ: Zona de Falla San Juan-Restauración; EPGFZ: Zona de Falla Enriquillo-Plantain Garden; DF: Formación Dajabon; MF: Formación Magua; CB: Cuenca del Civao; CR.: Cordillera Central; SJB: Cuenca de San Juan; EB: Cuenca de Enriquillo; AB: Cuenca de Azua. Líneas azules denominadas $A A^{\prime}$ y $B B^{\prime}$ : localización de los perfiles modelizados.

because they define the southern border of the accretionary prism and fragments of the Altamira Fm and Samaná complex, former oceanic basins accreted to the arc.

- South of the SFZ, Neogene to Present siliciclastic rocks of Cibao basin and Los Haitises limestone partially cover the Lower Cretaceous primitive island arc. This island arc includes volcanic and volcanoclastic rocks of Los Ranchos Fm and Amina-Maimón schists, which are petrologic and geochemical equivalents (e.g. Lewis et al., 1999, 2000, 2002; Escuder Viruete et al., 2002, 2006-b). Los Ranchos Fm is covered by the thick sedimentary sequence of Las Guayabas Fm (also known as Las Lagunas Fm), which is composed mainly of volcanoclastic sandstone.
- A broad serpentinized ultramafic belt named the Loma Caribe Peridotite. Its southern limit is the HFZ (Lewis et al., 1999; Draper et al., 1996) and related volcano-plutonic oceanic units (Escuder Viruete et al., 2007).

- South of the HFZ and north of BGFZ, there is the Late Jurassic volcano-plutonic assemblage and Lower Cretaceous Duarte Complex. The latter is mainly composed of metamorphic mafic and ultramafic volcanic rocks, and interpreted as an oceanic plateau constructed onto an oceanic crust (Palmer, 1979; Draper and Lewis, 1991; Lewis and Jiménez, 1991; Montgomery et al., 1994; Escuder Viruete et al., 2007, 2009).

- An Upper Cretaceous-Eocene magmatic arc 
sequence located between BGFZ and SJRFZ is mainly represented by the Tireo Fm. It was intruded by gabbro-tonalite batholiths whose geometries have been influenced by the displacements of the main fault/shear zones (Loma Cabrera, El Bao, Jumunuco, Macutico, El Río, La Jautia, see Figs. 3 and 4 for location), and ultramafic complexes (e.g., Lewis et al., 2002; Escuder Viruete et al., 2004; 2006-a; 2007; Stein et al., 2004). The HFZ and SJRFZ set the limits of the vulcano-plutonic zone of the island-arc (Duarte Complex and Tireo Fm) and the back arc basin.

- South of SJRFZ, the Peralta-Trois Rivières foldand-thrust belt (Peralta Belt on Fig. 2), the Neiba and Bahoruco mountain uplifts (Neiba and Bahoruco Sierra range on Fig. 2) and the Neogene-related basins (Heubeck and Mann, 1988; Dolan et al., 1991; Hernáiz Huerta, 2000), such as the Azua and Enriquillo basins (Mann et al., 1991; Mann, 1999; Díaz de Neira and Solé Pont, 2002) represent the Upper Eocene to Present age sedimentation. This occurred contempo- raneously with the oblique collision to the north and the subduction to the south of the Los Muertos deformed belt (LMDB on Fig. 1).

- At the south-western part of the island, an uplifted fragment of the Caribbean oceanic plateau crops out in the Bahoruco Sierra range. This terrane is composed of Upper Cretaceous basalts similar to those that form the substratum of the Caribbean Sea (Maurrasse et al., 1979; Sen et al., 1988; Mann, 1999; Kerr et al., 2002).

\section{Tectonic domains in the Central Cordillera}

The present study focuses on the Central Cordillera tectonic domains, which are bordered to the north by the HFZ and to the south by SJRFZ (Figs. 2 and 3). It comprises an Upper Jurassic-Upper Cretaceous thick magmatic sequence which includes a great variety of plutonic, volcanic, volcanoclastic and sedimentary

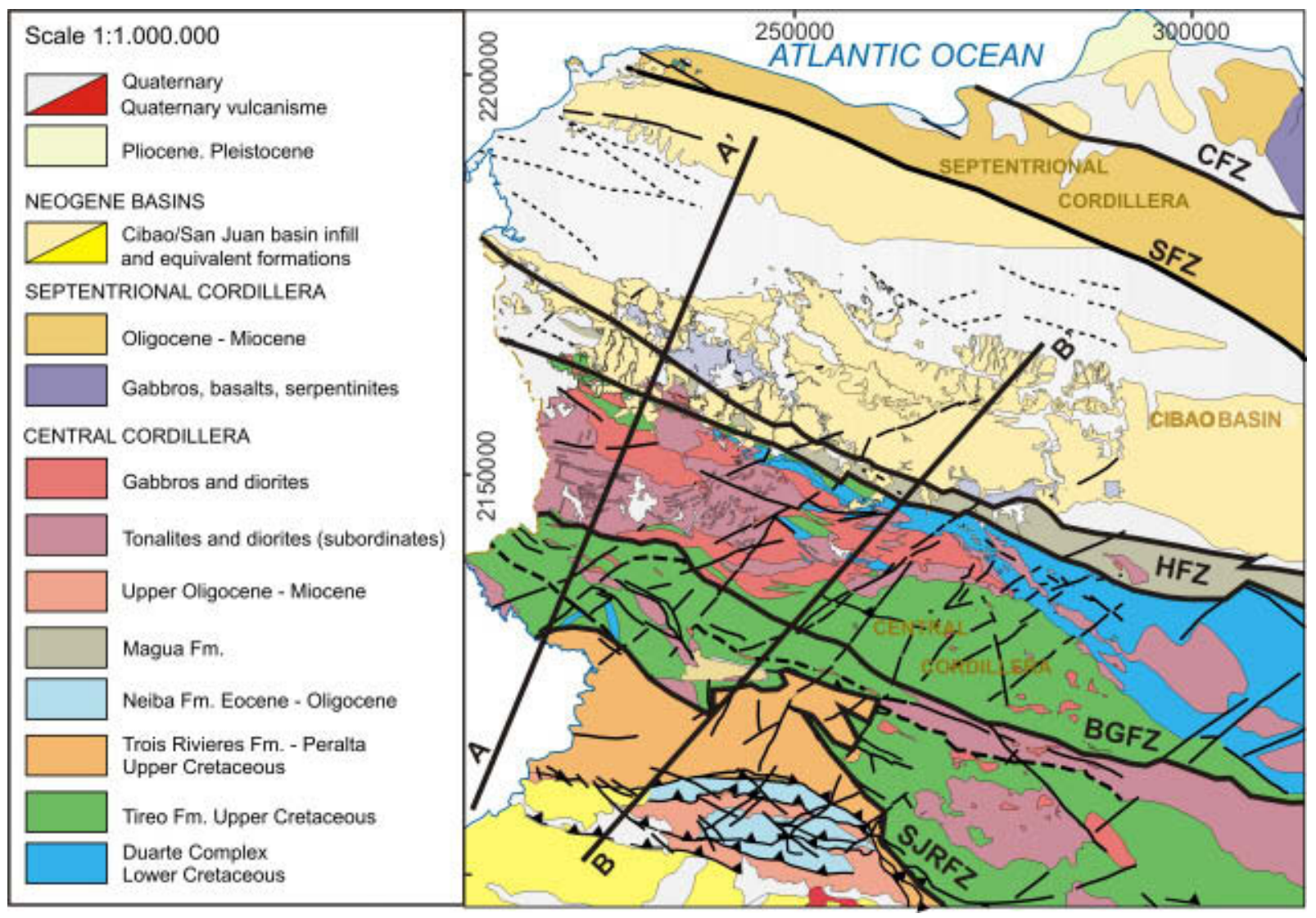

Figure 3. Geological map of the NW Dominican Republic, displaying the main modelled lithologies and the location of the modelled sections. The area displayed is the same as in Figure 6. UTM coordinates in m, Zone $19 \mathrm{~N}$.

Figura 3. Mapa Geológico del NO de la República Dominicana, mostrando las principals litologías modelizadas y la localización de las secciones modelizadas. El área mostrada es la misma que en la Figura 6. Las coordenadas UTM son en m, Zona $19 \mathrm{~N}$. 


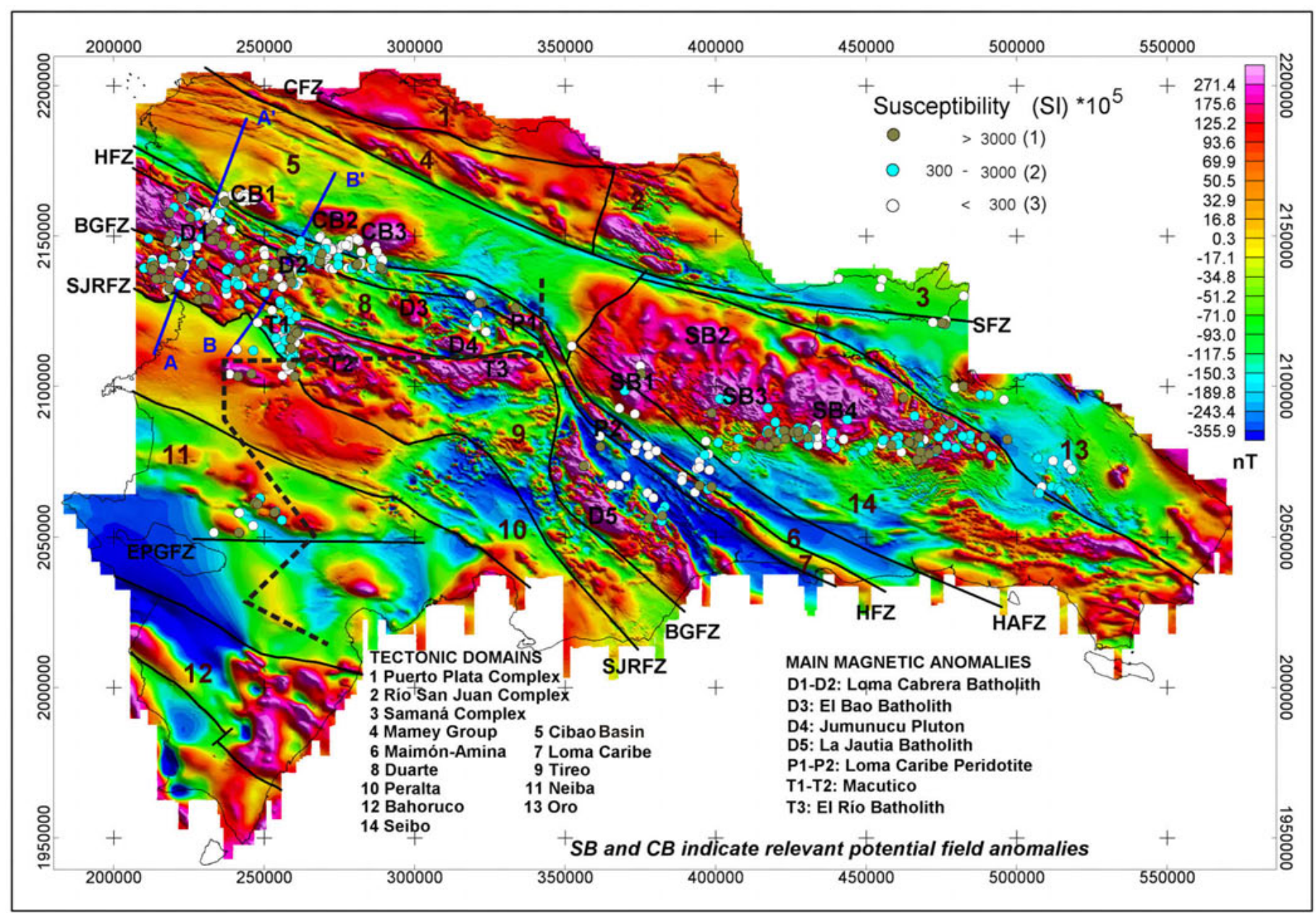

Figure 4. Equal area shaded relief Reduced to Pole Magnetic Field map with the location of samples. AA' and BB': 2D modelled profiles. UTM coordinates in $\mathrm{m}$, Zone $19 \mathrm{~N}$. Susceptibility distribution: (1) Ferromagnetic rocks (mainly gabbroic rocks, diorites, basalts, andesites and serpentinites); (2) Intermediate magnetic rocks (tonalites, basic tuffs); (3) Paramagnetic rocks (acid igneous and metasedimentary rocks). CFZ: Camú Fault Zone; SFZ: Septentrional Fault Zone; HFZ: Hispaniola Fault Zone; HAFZ: El Hatillo Fault Zone. BGFZ: Bonao-La Guácara Fault Zone; SJRFZ: San Juan Restauración Fault Zone; EPGFZ: Enriquillo-Plantain Garden Fault Zone. Details about magnetic properties on Table I. Discontinuous black line: location of the seismic profiles mentioned in the text.

Figura 4. Mapa de relieve sombreado del Campo Magnético reducido al Polo mostrando la localización de las muestras. AA' y BB': perfiles 2D modelizados. Coordenadas UTM en m, Zona $19 \mathrm{~N}$. Distribución de la susceptibilidad: (1) rocas ferromagnéticas (principalmente rocas gabroicas, dioritas, basaltos, andesitas y serpentinitas); (2) rocas magnéticas intermedias (tonalitas, tobas máficas); (3) rocas paramagnéticas (rocas ígneas ácidas y metasedimentarias). CFZ: Zona de Falla de Camú; SFZ: Zona de Falla Septentrional; HFZ: Zona de Falla de La Española; HAFZ: Zona de Falla El Hatillo. BGFZ: Zona de Falla Bonao-La Guácara; SJRFZ: Zona de Falla San Juan-Restauración; EPGFZ: Zona de Falla Enriquillo-Plantain Garden. Detalles sobre las propiedades magnáticas en la Tabla 1. Línea negra discontinua: localización de los perfiles sísmicos mencionados en el texto.

rocks (e.g., Escuder-Viruete et al., 2006-a, 2007). The rocks were very heterogeneously deformed and the Duarte Complex was also metamorphosed to greenschist and amphibolite facies conditions, but the textures of the protoliths are often preserved. From bottom to top, four main domains have been mapped (Fig. 3): (1) the Upper Jurassic volcano-plutonic oceanic assemblage; (2) a Lower Cretaceous mafic (mainly picrites and high-Mg basalts) Duarte
Complex, that represents an oceanic plateau; (3) the overlying Upper Cretaceous intermediate to acid volcanic and sub-volcanic rocks of the Tireo Fm, related to subduction processes under the oceanic plateau; and (4) the tholeiitic, transitional and alkaline basalts, representing new plume-related intraplate magmatism in the Late Campanian-Maastrichtian. The subduction processes gave rise to a typical island arc made of extruded tholeiitic to calc-alkaline magmas 
Ayala, C., et al., 2017. High resolution magnetic, regional gravity and petrophysical... Boletín Geológico y Minero, 128 (3): $611-631$

and intruded by the gabbro to tonalitic batholiths of Loma Cabrera (see Fig. 4). This magmatic sequence is interpreted as a crustal section of an intra-oceanic island arc built on the Caribbean oceanic crust and the overlying Duarte Complex oceanic plateau.

These three tectonic domains are bounded by several WNW-ESE-trending, sinistral strike-slip fault zones (Fig. 3; Contreras, 2004; Stein et al., 2004; Urien and Joubert, 2004): HFZ, BGFZ and SJRFZ. HFZ is the longest tectonic feature and juxtaposes the AminaMaimón schist belt against the units of the Central Cordillera (Draper and Lewis, 1991). In the study area, serpentinite lenses equivalent to Loma Caribe serpentinized peridotite occur in the northern boundary of the HFZ. These lenses are tectonically interleaved with Central Cordillera rocks. The timing of the movement along this fault in the Central Cordillera is poorly constrained, but the HFZ cuts Lower Eocene to Oligocene rocks and the fault is unconformably overlain by Upper Oligocene rocks, although minor activity has been recognized until the present day. Sinistral, strike-slip motion took place in the HFZ across a kilometric-scale deformation zone, including ductile to ductile-brittle shearing (Draper and Lewis, 1991; Contreras, 2004). The cessation of the Caribbean island-arc activity is recorded in the Central Cordillera with the subsequent shallow-marine carbonate sedimentation that took place during the Maastrichtian. Following an eruptive hiatus, subduction-related magmatism renewed locally in the Eocene with intrusion of dioritic to tonalitic plutons and eruption of calc-alkaline basalts/andesites.

The modelling is based on two geological profiles from Escuder-Viruete et al. (2006a), which cross the main structures in the Central Cordillera. Looking NNE from the Loma Cabrera batholith, the macrostructure comprises several asymmetrical anticlines and synclines with WNW-ESE axes and a NEvergence separated, on occasions, by high-angle reverse faults. Looking SSW from the Loma Cabrera batholith, the Tireo Fm is defined by felsic rocks in the upper part of the sequence and an alternation of bands of intermediate and basic metavolcanic rocks in the lower part, with a general dip to the NE (Escuder-Viruete et al., 2006a), and separated by NEdipping, mid-to-high-angle thrust faults. This macrostructure also defines a tectonic imbrication of compositionally different metavolcanic rocks of the Tireo Fm in a SW-directed fold-and-thrust belt, with the upper structural levels situated towards the NE. In addition, there was a left-lateral oblique component of displacement during thrusting.

\section{Geophysical data}

\section{Aeromagnetic data and methods}

Aeromagnetic data (Fig. 4) come from an early survey in 1997 with line separation of $1 \mathrm{~km}$ and nominal elevation of $120 \mathrm{~m}$, and a later survey in 1999 with line separation of $500 \mathrm{~m}$ over the Central and Oriental Cordilleras and the SW border of the Dominican Republic (where there was no coverage from the former survey). Both surveys were acquired and processed by the Compagnie Générale de Géophysique (1997) for the SYSMIN European Union Program. Data were gridded at $250 \mathrm{~m}$ and several procedures were followed (e.g. micro-levelling, filtering of frequencies greater than Nyquist) to ensure data quality (i.e. avoiding aliasing, etc.). Qualitative interpretation of the data has been made using the magnetic data reduced to the pole, RTP (Fig. 4) and the modelling with the total magnetic field (after subtracting (GRF). The RTP was calculated assuming a local inclination of $48^{\circ} \mathrm{N}$ and declination of $10^{\circ} \mathrm{W}$. The main tectonic domains of the island are clearly delineated by the magnetic anomalies (Figure 6A).

The magnetic field displays two main features: (1) a well-defined zonation in NW-SE bands that correlate with the tectonic units forming the land mass, delineated by a series of prominent magnetic features, along the shear zones that limit these tectonic units (names within Figures 3 and 4); and (2) intense anomalies (i.e. more than $150 \mathrm{nT}$ ) due to an ubiquitous ferromagnetic magmatism widespread all over the whole island, and in particular over the batholiths of the Central Cordillera. These magnetic anomalies also allow an accurate mapping of gabbro-tonalitic batholits (Fig. 4: Loma Cabrera D1-D2, El Bao D3, Jumunuco D4, La Jautia D5, MacuticoT1-T2, EI RíoT3).

The magnetic intensity and gradients reach maximum values not only where these volcano-plutonic rocks crop out but also in areas covered by fluviomarine sediments. This indicates the proximity to the surface of the plutonic rocks beneath the sediments. In general, depths to magnetic sources are shallow (hundreds of meters) in the volcano-plutonic areas of the island, and deeper (of the order of 1-5 kilometres) in areas with significant sedimentary infill as the Cibao, Azua and Enriquillo basins (see Fig. 2 for location). For instance, northeast of HFZ there are two zones of different magnetic texture: to the north, in the Cibao basin, local anomalies CB1 to CB3 (Fig. 4) are due to buried bodies at a depth of several kilometres, whereas towards the SE, within the Seibo and Oro tectonic units, anomalous bodies under Haitises limestone are much shallower. 
The major magnetic discontinuities correlate with the fault zones and shear zones cutting the island from NE to SW, (Fig. 4). These are: CFZ, SFZ; EI Hatillo Fault Zone (HAFZ); HFZ; BGFZ and SJRFZ. Magnetic expression of the Central Cordillera is clearly enclosed between HFZ, partially demagnetised, and SJRFZ, which shows magnetic materials within. Some other fault zones are also either demagnetized (SFZ) or intruded by magnetic bodies (BGFZ).

The magnetic anomaly pattern of the map also allows the tracing of much more detailed structures and lithologies without ambiguities, which greatly help geological mapping. This is the case of some geological units mapped by using their magnetic signature (see García-Lobón and Rey-Moral, 2002a, b). For instance, magnetic directions over the volcanodetritic formations in the Seibo and Oro units clearly show the faulting and folding of these formations (Los Ranchos and Las Guayabas Fms; García-Lobón and Ayala, 2005, 2007).

\section{Gravity data and methods}

The Bouguer anomaly map of the Dominican Republic (Fig. 5) was constructed from a compilation made by the National Geospatial-Intelligence Agency (NGA). The NGA database contains information from several surveys carried out by different research centres (IFREMER, Royal Astronomical Society, Cambridge University, Lamont-Doherty Geological Observatory and Woods Hole Oceanographic Institution amongst others) between 1939 and 1991. The NGA available data is from 3012 stations, with precision of $\pm 2 \mathrm{mGal}$ and density reduction of 2.67 $\mathrm{Mg} / \mathrm{m}^{3}$. Although the distribution of the stations is sparse and the grid cell size is $250 \times 250 \mathrm{~m}$, the Bouguer anomaly is consistent with the main faults and shear zones that limit the different tectonic units. Outside the study area, there are places where the data are too scarce for gridding with that cell size, hence the blanks in Figure 5. The data has been gridded using a minimum curvature algorithm in Oasis Montaj software ${ }^{\circledR}$.

North of SFZ, the anomaly map displays the gravity maxima, up to c. $60 \mathrm{mGal}$, caused by the high pressure metamorphic complexes: Puerto Plata, Río San Juan and Samaná, that are made of high density amphibolites, gabbroic and ultrabasic suites, eclogites, mafic schists and gneiss assemblages. South of CFZ, the Mamey Group turbiditic unit is characterized by a rather flat anomaly between -7.5 to $7.5 \mathrm{mGal}$. The SFZ is delineated by contrasting gravity signatures between the Cordillera Septentrional and the Cibao basin. At the eastern end of the Cibao basin, Los Haitises limestone (Fig. 2) partially covers the Lower Cretaceous primitive island-arc (Los Ranchos Fm, Fig. 2): anomalies SB1 to SB4 indicate the areal extension of the arc. South of HFZ, intense anomalies, up to 70 to $80 \mathrm{mGal}$, from gabbro-tonalite batholiths and igneous complexes of the Central and Eastern Cordilleras are identifiable (e.g., Loma Cabrera D1-D2, and El Bao D4, Fig. 3), forming a prominent elongated maximum that crosses the island from NW to $\mathrm{SE}$, with relative maxima superimposed. In its north-western part, the Central Cordillera maxima reaches values up to $90 \mathrm{mGal}$, flanked by rather steep gradients towards Cibao basin and San Juan Basin. Elongate, negative, Bouguer anomalies reaching more than $-25 \mathrm{mGal}$ in places, occur over the Tertiary rocks covering Peralta unit, the Cibao basin, the San Juan Basin and the Enriquillo Basin. These features suggest a significant sedimentary thickness. Because of the scarcity of the gravity data, the Bouguer map does not cover the whole extension of the Bahoruco Range. Nonetheless, the available gravity data suggest a zone of relative maxima with a positive N-S gradient. The origin of this anomaly may be the existence of high density rocks, such as mafic and ultramafic rocks of the underlying oceanic plateau.

The Bouguer gravity anomaly includes the contribution from the lateral changes in density occurring at deep and shallow depths. In order to model the upper crust of the Central Cordillera (depths up to 14 $\mathrm{km})$, a residual Bouguer anomaly has been calculated (Fig. 6B). This procedure isolates the deep-seated anomalies originated at Moho depths (regional anomalies) from the ones originated at shallower depths (residual anomalies). After several trials, the residual that has the best correlation with the surface geology is the one computed by subtracting a second degree polynomial to the Bouguer anomaly. This residual highlights the main tectonic domains. Minimum values from -40 to $-70 \mathrm{mGal}$ occur over the Peralta, Cibao, San Juan and Enriquillo Basins, thus giving further evidence of the thick Tertiary sedimentary cover (at least 2-5 km). Positive anomalies (up to $65 \mathrm{mGal}$ ) occur over the intrusive bodies within Central and Eastern Cordilleras and Río San Juan Complex. The SFZ is clearly delimited by a steep gradient. Another steep gradient, south of the Central Cordillera, coincides with SJRFZ.

\section{Petrophysical data and methods}

The petrophysical analysis consists of 586 measurements of density and magnetic susceptibility as well 
Ayala, C., et al., 2017. High resolution magnetic, regional gravity and petrophysical... Boletín Geológico y Minero, 128 (3): $611-631$

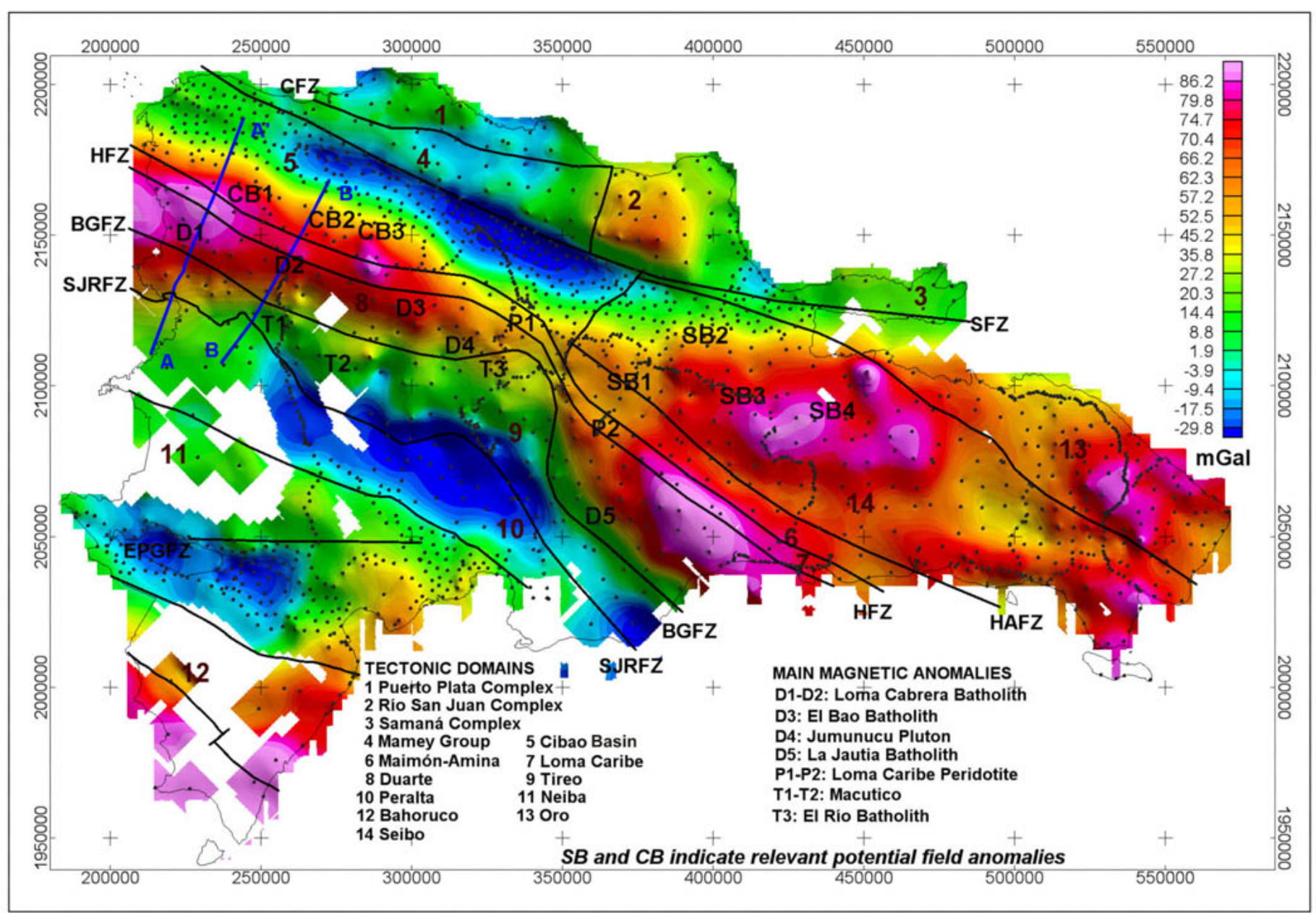

Figure 5. Equal area shaded relief Bouguer Anomaly map with the gravity point data location. Superimposed are shown the tectonic domains and magnetic anomaly zones. AA' and BB': 2D modelled profiles. UTM coordinates in m, Zone 19 N. CFZ: Camú Fault Zone; SFZ: Septentrional Fault Zone; HFZ: Hispaniola Fault Zone; HAFZ: El Hatillo Fault Zone. BGFZ: Bonao-La Guácara Fault Zone; SJRFZ: San Juan Restauración Fault Zone; EPGFZ: Enriquillo-Plantain Garden Fault Zone. The main magnetic anomalies appear also labelled for comparison between its gravimetric and magnetic response.

Figura 5. Mapa de relieve sombreado de la Anomalía de Bouguer mostrando la localización de los datos puntuales de gravedad. Se muestras superpuestos los dominios tectónicos y las zonas de anomalía magnética. $A A^{\prime}$ y $B B^{\prime}$ : perfiles $2 D$ modelizados. Coordenadas UTM en m, Zona 19 N. CFZ: Zona de Falla de Camú; SFZ: Zona de Falla Septentrional; HFZ: Zona de Falla de La Española; HAFZ: Zona de Falla EI Hatillo. BGFZ: Zona de Falla Bonao-La Guácara; SJRFZ: Zona de Falla San Juan-Restauración; EPGFZ: Zona de Falla Enriquillo-Plantain Garden. Las principales anomalías magnéticas aparecen también etiquetadas para comparar su respuesta gravimétrica y magnética.

as 104 measurements of remanent magnetization, distributed across the whole island (Fig. 4).

Laboratory measurements of density have been made on hammer-cut samples $(0.3-0.6 \mathrm{~kg})$ by weighing them in air and water. These samples come from $4-5 \mathrm{~kg}$ of rock collected in the field. From each of these samples, powder ( $2 \mathrm{~mm}$ grid pass) is obtained and magnetic susceptibility determined in a kappabridge (KLY-2 instrument of AGICO Inc.); the mass of the powder is measured, and the kappabridge values are converted to susceptibility values, then multi- plied by the density of the sample to obtain volume susceptibility. Finally, non-oriented 2-inches prisms were cut and rock remanent magnetization was measured in a spin magnetometer (JR5, also of AGICO Inc.). Sensitivities are of the order of $0.01 \mathrm{Mg} / \mathrm{m}^{3}$, $2 \times 10^{-6} \mathrm{SI}$ units, and $3 \times 10^{-6} \mathrm{~A} / \mathrm{m}$, respectively. Precision is $0.02 \mathrm{Mg} / \mathrm{m}^{3}$ for density, and better than $5 \%$ for the magnetic measurements. The main petrophysical groups have been characterized as: (1) high density rocks that include basalts, gabbroic and ultrabasic plutonic rocks, amphibolites and eclogites, with aver- 

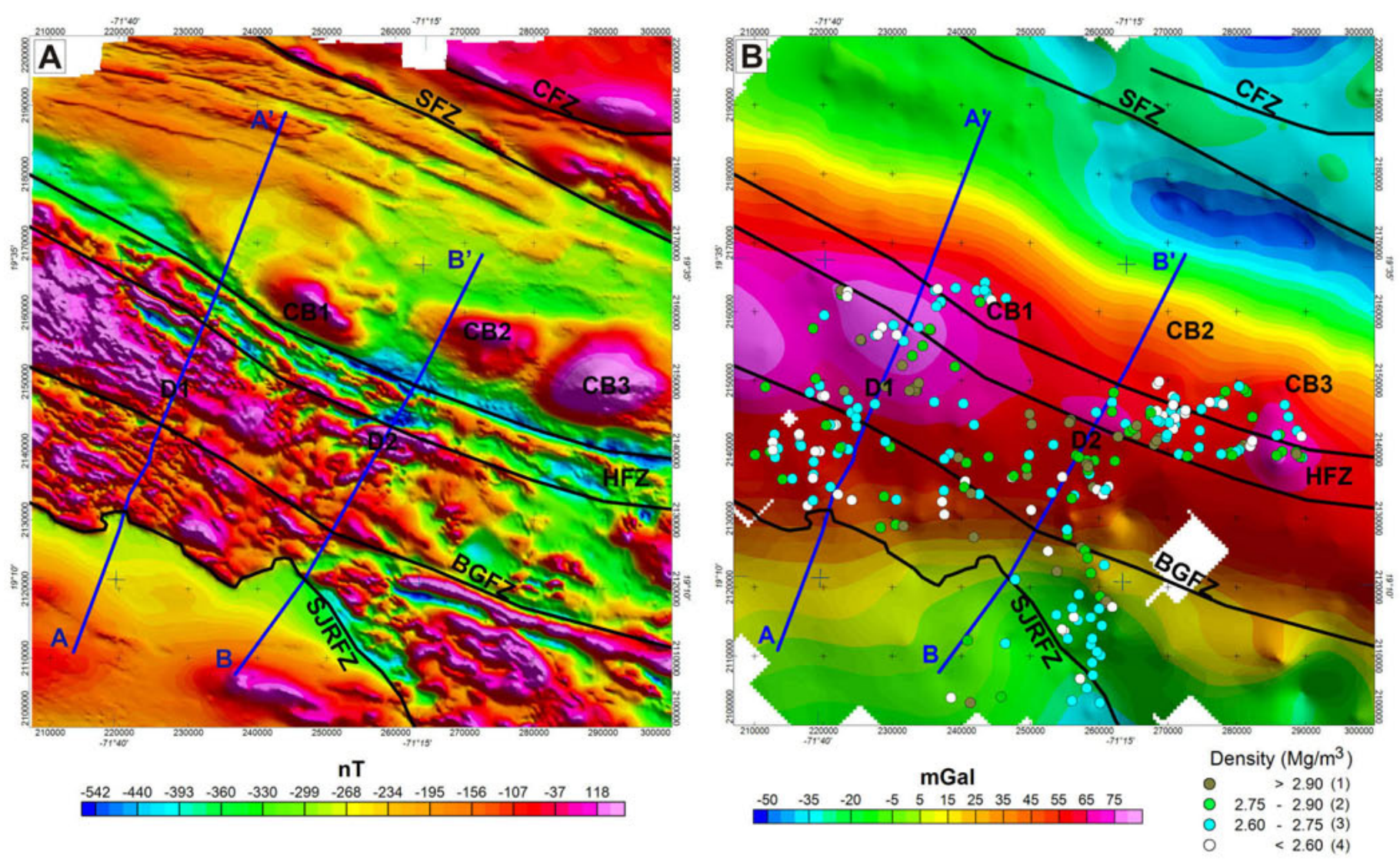

Figure 6. (A) Equal area shaded relief of the RTP magnetic anomaly of the NW Dominican Republic; (B) Equal intensity shaded relief of the residual Bouguer anomaly for the same area with the density distribution of samples: (1) Eclogites, gabbros, amphibolites, diabases and ultrabasic rocks; (2) andesites, basalts and diorites; (3) dacites, basic tuffs, tonalites, schists and gneiss; (4) acid igneous rocks and slates. Location of profiles $\mathrm{AA}^{\prime}$ and $\mathrm{BB}^{\prime}$ is also displayed. UTM coordinates in $\mathrm{m}$, Zone $19 \mathrm{~N}$.

Figura 6. (A) Mapa de relieve sombreado de la anomalía magnética del RTP en el NO de la República Dominicana; (B) Mapa de relieve sombreado de la anomalía residual de Bouguer para la misma área mostrando la densidad de distribución de muestras: (1) eclogitas, gabros, amfibolitas, diabasas y rocas ultrabásicas; (2) andesitas, basaltos y dioritas; (3) dacitas, tobas máficas, tonalitas, esquistos y gneises; (4) rocas ígneas ácidas y pizarras. Se muestra la localización de los perfiles $A A^{\prime}$ y BB'. Coordenadas UTM en m, Zona $19 \mathrm{~N}$.

age densities higher than $2.6 \mathrm{Mg} / \mathrm{m}^{3}$; (2) low density rocks that include granitoids, metasedimentary and acid volcanic rocks, with average densities lower than $2.6 \mathrm{Mg} / \mathrm{m}^{3}$; (3) the magnetic markers of the area that include andesites, basalts, gabbros, diorites, serpentinites, and some ultrabasic rocks and acid volcanic rocks; and (4) the paramagnetic rocks, mostly metasedimentary and granitic. The main results are summarised in Table I which shows that the susceptibility values are grouped by ranges due to the typical polimodal distribution of this parameter.

The petrophysical characteristics of the sampled lithologies that are included in the models are summarised as follows (García-Lobón and Rey-Moral, 2002a; García-Lobón and Ayala, 2005, 2007):

- In theTireo Fm, the segment limited by the SJRFZ and BGFZ, high density basic and intermediate igneous rocks are ferromagnetic (volcanic rocks and intrusive tonalites, diorites and gabbros). The low density acid volcanic rocks are of bimodal susceptibility and the metasedimentary rocks are paramagnetic.

- Within the igneous complexes, average densities range from $2.57 \mathrm{Mg} / \mathrm{m}^{3}$ (granites) to $3.00 \mathrm{Mg} / \mathrm{m}^{3}$ (ultramafic rocks). Ferromagnetism is predominant in the gabbroic and ultramafic rocks while tonalites are mainly bimodal, with magnetic and paramagnetic zones in the major batholiths (Loma Cabrera, El Bao, Macutico, etc.) and the main volcanic axis of the island. Susceptibilities of the analysed samples range mainly from moderately ferromagnetic (c. $0.5 \%$ in magnetite content; 6 samples within this range) to highly ferromagnetic (c. 1.6\% in magnetite content, 12 samples within this range). From the available aero- 
Ayala, C., et al., 2017. High resolution magnetic, regional gravity and petrophysical... Boletín Geológico y Minero, 128 (3): $611-631$

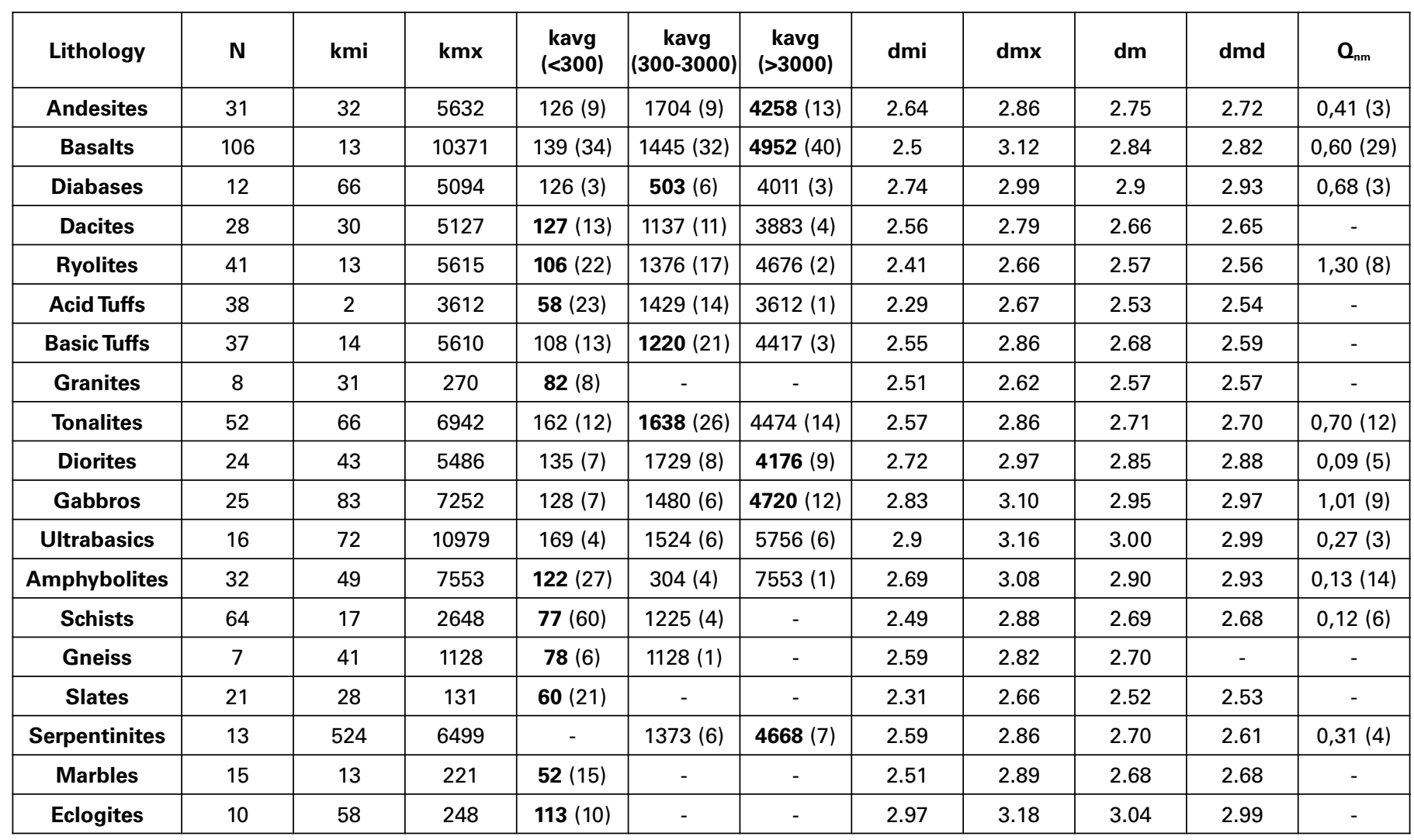

Tabla I. Density and magnetic susceptibility of 586 analyzed rock samples from the Dominican Republic. N: number of samples (see figures 3, 4 and 5 for location). kmi, kmx: minimum and maximum susceptibility. kavg: average susceptibilities (in SIx105) for 0-300, 300-3000, and $>3000$ ranges (in bold, average from range with highest number of samples). dmi, dmx, dm, dmd: minimum, maximum, average and mode of density in Mg/m3. Onm: median of Koenigsberger parameter. Susceptibility and Koenigsberger parameter values are referred to the number of samples indicated within brackets.

Tabla I. Densidad y susceptibilidad magnética de las 586 muestras de roca analizadas de la República Dominicana. N: número de muestras (ver Figuras 3, 4 y 5 para la localización). kmi, kmx: susceptibilidad minima y máxima. kavg: susceptibilidad promedio (en Slx105) para los rangos 0-300, 300-3000, y >3000 (en negrita, promedio del rango con el mayor número de muestras). dmi, dmx, dm, dmd: mínimo, máximo, promedio y moda de la densidad en $\mathrm{Mg} / \mathrm{m}^{3}$. Onm: media del parámetro de Koenigsberger. Los valores de susceptibilidad y del parámetro de Koenigsberger están referidos el número de muestras indicada entre paréntesis.

magnetic maps, this magnetic behaviour seems to be characteristic of the lithologies of the igneous complexes in the Central Cordillera. The Yautia gabbros and Loma-Caribe peridotites are ferromagnetic; tonalitic-dioritic intrusives of Oriental Cordillera are also ferromagnetic.

- Rocks from Duarte complex, limited by BGFZ and HFZ, display typical density values of volcanic, plutonic and metamorphic rocks, and typical bimodality ranging from paramagnetic to ferromagnetic susceptibilities. Metasedimentary and metamorphic units are mainly paramagnetic (such as, in order of increasing paramagnetism, the Magua, Dajabón and AminaMaimón Fms), with the exception of some basalts and tonalites that intrude these units. The same occurs in the Río San Juan high-P complex, and
Peralvillo and Siete Cabezas Fms. Lithologies in the Río Verde and Samaná complexes are mainly of high density and are paramagnetic.

\subsection{Geophysical models}

In order to characterize the lateral boundaries of the tectonic domains (see a detailed geological map of the area in Fig. 3) and the nature of the basement, two $2.5 \mathrm{D}$ residual gravity and magnetic models (Figs. 7, 8 and 9) have been elaborated. These profiles run along two geological cross-sections that contain detailed structural and lithological data up to a depth of 1200 $\mathrm{m}$ (Escuder Viruete et al., 2006-a) which are displayed over the modelled profiles (Figs. 7 and 9). The forward 


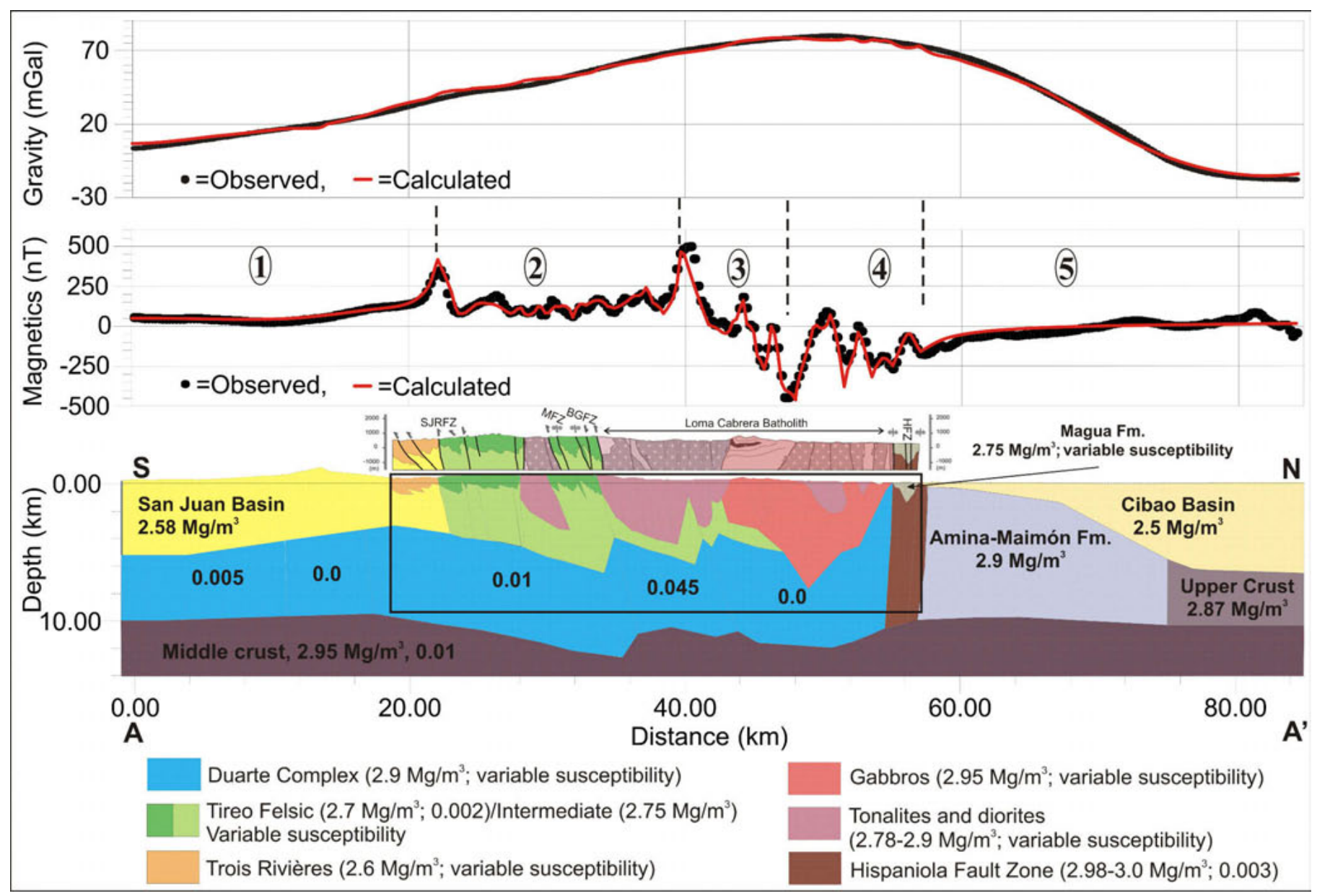

Figure 7. Magnetic and gravity model along section $A A^{\prime}$ with the geological cross-section from Escuder-Viruete et al. (2006a) on top. Numbers without units, magnetic susceptibility in SI used in the model ( 0.0 if no label on the model). See figure 6 for location. See details of the uppermost crust beneath the geological section (area within the black rectangle) on Fig. 7.The numbers 1 to 5 on the magnetic anomaly indicate the five magnetic domains described on the text. SJRFZ: San Juan Restauración Fault Zone; MFZ: Macutico Fault Zone; BGFZ: Bonao-La Guácara Fault Zone. Same horizontal and vertical scale.

Figura 7. Modelo magnético y gravimétrico a lo largo de la sección AA' con el corte geológico de Escuder-Viruete et al. (2006a) encima. Números sin unidades, susceptibilidad magnética en SI usada en el modelo (0.0 si no hay etiqueta en el modelo). Ver Figura 6 para la localización. Ver detalles de la corteza superior más alta bajo el corte geológico (área con el rectángulo negro) en la Figura 7. Los números 1 a 5 en la anomalía magnética indican los cinco dominios magnéticos descritos en el texto. SJRFZ: Zona de Falla de San JuanRestauración; MFZ: Zona de Falla de Macutico; BGFZ: Zona de Falla de Bonao-La Guácara. Misma escala vertical y horizontal.

modelling has been performed using GM-SYS software (by Geosoft ${ }^{\circledR}$ ). The methods used to calculate the gravity and magnetic model response are based on the methods of Talwani et al. 1959, and Talwani and Heirtzler, 1964, and use the algorithms described in Won and Bevis, 1987. The 2.5D calculations are based on Rasmussen and Pedersen, 1979. Reference density of the residual Bouguer anomaly is 2.67 $\mathrm{Mg} / \mathrm{m}^{3}$. All density and magnetic susceptibility values used for each lithology in our models fall within the limits of the petrophysical data: density values are near the average density of each measured lithology, and magnetic susceptibility values are, in general, close to the different measured modes (paramagnetic, intermediate or ferromagnetic; see Table I).

The models have been extended at both ends of the profiles to avoid edge effects and we have assumed that the Curie isotherm lies within the lower crust. This assumption is based on the calculation of the approximated depth to the Curie isotherm from the magnetic data, using the Radial Power Spectra (following Ross, et al., 2006) and the results indicate, for the study area, a Curie depth of c. $15 \mathrm{~km}$. In the models, the only available geophysical information is the potential field data (Fig. 6). The geometry and depth extension of the structures depicted on the 


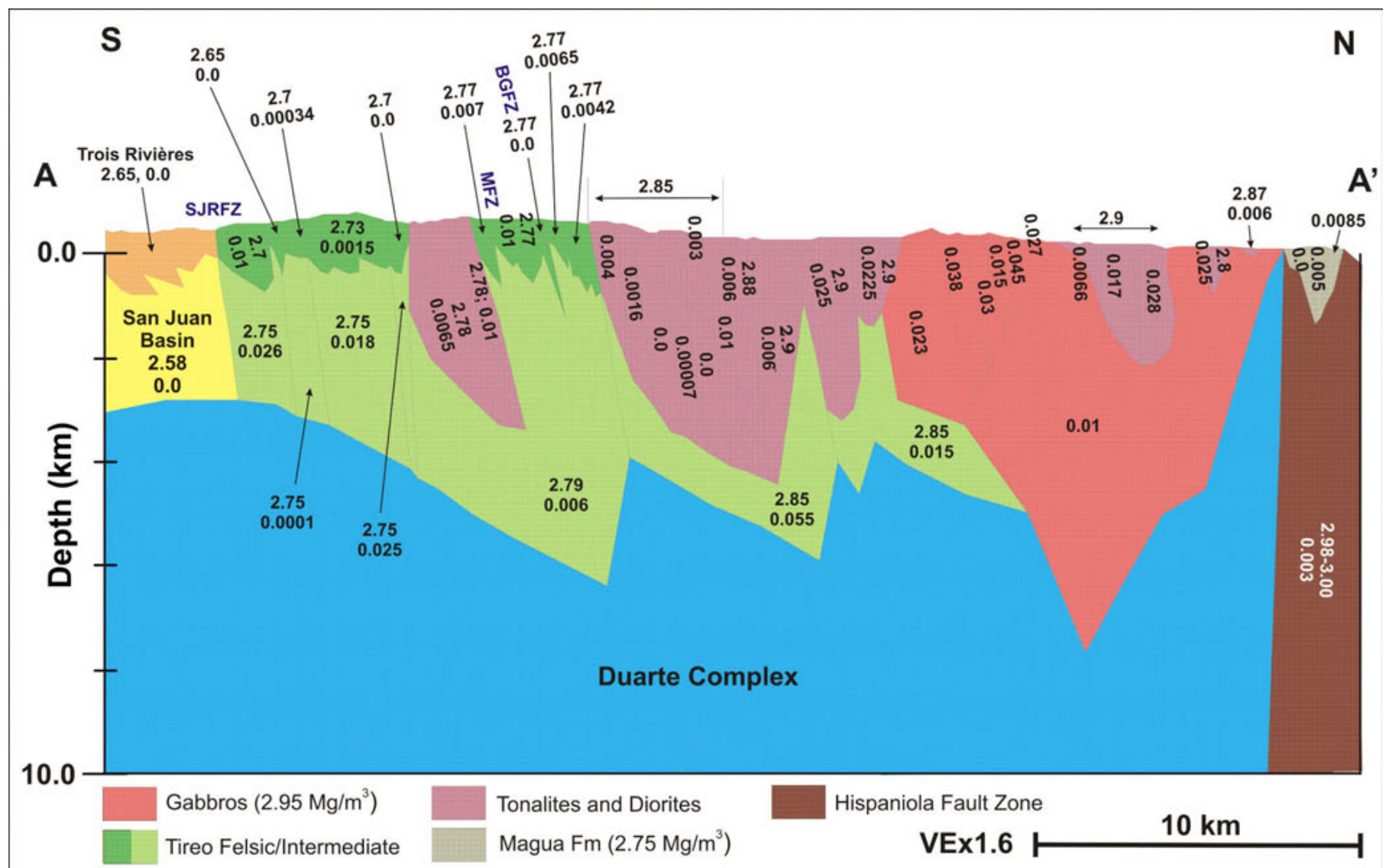

Figure 8. Detail of the section $A^{\prime}$ (area within the black rectangle in Fig. 7) showing the values used in the model: density (first number) in $\mathrm{Mg} / \mathrm{m} 3$ and magnetic susceptibility (second number) in SI. SJRFZ: San Juan Restauración Fault Zone; MFZ: Macutico Fault Zone; BGFZ: Bonao-La Guácara Fault Zone.

Figura 8. Detalle de la sección $A A^{\prime}$ (área con el rectángulo negro en la Figura 7) mostrando los valores utilizados en el modelo: densidad (primer número) en Mg/m3 y susceptibilidad magnética (segundo número) en SI. SJRFZ: Zona de Falla de San Juan-Restauración; MFZ: Zona de Falla de Macutico; BGFZ: Zona de Falla de Bonao-La Guácara.

geological cross-sections are modelled by the combination of the gravity, magnetic and petrophysical data. Particularly, the magnetic modelling resolves with more accuracy than gravity the magnetic structures depicted in the geological profiles and allows their geometrical projection to depth. The modelled depths of the different magnetic bodies are in agreement with previous estimations of the anomalous sources using Werner and Euler deconvolution (García-Lobón et al., 2007)

\section{Results and discussion}

Residual gravity anomalies (Fig. 6B) are mainly caused by the occurrence of laccolithic-shaped intrusions of contrasting density, notably the high-volume of gabbroic rocks required to explain the gravity max- imum in the Loma Cabrera batholith. The depth and shape of San Juan and Cibao Basins have been modelled to fit the gradient towards the edges of the model, assuming a typical density for the Eocene to Quaternary sedimentary rocks. Amina-Maimón is mainly paramagnetic (as in model $A A^{\prime}$ ), except for some areas that are intruded with basalts and tonalites (as in model BB'$^{\prime}$ ). The crust beneath Duarte Complex has been modelled assuming that is made of mafic igneous rocks that were metamorphosed to different degrees, with a standard value for its magnetic susceptibility $\mathrm{k}=0.01 \mathrm{SI}$ and a density of 2.95 $\mathrm{Mg} / \mathrm{m}^{3}$.

In the magnetic field, five domains can be distinguished (Figs. 4, 6A, 7 and 9):

1) A southern magnetic domain characterized mainly by susceptibility changes across Duarte Complex (0.005-0.0-0.01 SI in model $\mathrm{AA}^{\prime}, 0.005-0.002-$ 




Figura 9. Magnetic and gravity model along section BB' with the geological section from Escuder-Viruete et al. (2006a) on top. Numbers without units, magnetic susceptibility in SI used in the model ( 0.0 if no label on the model). See location on Figs. 3,4 and 5 . The numbers 1 to 5 on the magnetic anomaly indicate the five magnetic domains described on the text. Same horizontal and vertical scale.

Figure 9. Modelo magnético y gravimétrico a lo largo de la sección BB' con el corte geológico de Escuder-Viruete et al. (2006a) encima. Números sin unidades, susceptibilidad magnética en SI usada en el modelo (0.0 si no hay etiqueta en el modelo). Ver Figuras 3, 4 y 5 para la localización. Los números 1 a 5 en la anomalía magnética indican los cinco dominios magnéticos descritos en el texto. Misma escala vertical y horizontal.

$0.03 \mathrm{SI}$ in model $\left.\mathrm{BB}^{\prime}\right)$. The limit of this domain in model $\mathrm{AA}^{\prime}$ is a maximum of c. $275 \mathrm{nT}$, due to the transition between the San Juan Basin-Trois Rivières Fm, consisting of paramagnetic metasedimentary rocks, and the Tireo $\mathrm{Fm}$, that consists of an alternation of metamorphic, mainly paramagnetic, and igneous, mainly ferromagnetic, rocks. This limit is less conspicuous in model BB', where approximately correlates with Macutico Fault Zone (MFZ in Figs. 2 and 9).

2) Short wavelength anomalies corresponding to susceptibility changes across volcanic rocks of the Tireo $\mathrm{Fm}$ and the tonalite-diorite intrusive bodies.
These anomalies interfere with the long wavelength Duarte Complex magnetic responses, that in this section of the profile have susceptibility values from 0.01 to $0.045 \mathrm{SI}$ in model $\mathrm{AA}^{\prime}$ and from 0.01 to $0.03 \mathrm{SI}$ in model BB'.

3) A steep magnetic gradient in the Duarte Complex is due to an abrupt change from ferromagnetic to paramagnetic character, and is overlapped by a set of short wavelength, high amplitude anomalies, generated by the ferromagnetic materials of Loma Cabrera batholith.

4) Towards the northern part of profile $A A^{\prime}$, there 
are two short wavelength, small amplitude anomalies associated with the HFZ (Fig. 7). In profile BB', there are two short wavelength, small amplitude anomalies: one that overlaps the anomaly from Loma Cabrera batholith, associated to some rocks from Tireo Fm, and the other generated by the HFZ.

5) The northern magnetic segment of long wavelength and small amplitude anomalies that corresponds to the Cibao basin and its underlying crust. That crust is mainly paramagnetic in profile $A A^{\prime}$, whereas in profile $B^{\prime}$ there is a relatively low amplitude, medium wavelength anomaly that reflects the effect of the Amina-Maimón schists and metamorphic rocks that crop out towards the NE.

It is worth noting that lateral changes in the susceptibilities of gabbros are necessary to adjust the short wavelength component of the magnetic data, and these values are justified by the laboratory measurements (please note that Table I is just a summary of our Dominican Republic petrophysical database). Keeping the adjustment of the model, it is possible to make small changes in the model susceptibilities (e.g. $20 \%$ ) only when susceptibility values are to the order of $0.001 \mathrm{SI}$. The range of possible changes for higher susceptibilities, as is the case for some of the lithologies on the models is reduced to $10 \%$ or less, in particular when magnetic bodies are near the surface (less than $3 \mathrm{~km}$ in depth).

Modelling results show that theTireo Fm has thicknesses of between 3 and $7 \mathrm{~km}$, and includes dense intrusive bodies of contrasting magnetization. These intrusive bodies reach, in places, up to $7.5 \mathrm{~km}$ in depth, close to the top of Duarte Complex. The Duarte Complex forms a heterogeneous layer that extends across the section from the HFZ to the $\mathrm{N}$ and beneath the San Juan Basin to the S, with thicknesses from 5 to $7 \mathrm{~km}$. Depth of the sediments in the Cibao Basin reach up to $6.5 \mathrm{~km}$ and in San Juan Basin, nearly 6 $\mathrm{km}$. Densities and depths of San Juan and Cibao Basins sediments are in agreement with those obtained from the seismic profiles (Electroconsult, 1981; Mann and Lawrence, 1991). From our modelling, the minimum depth of the HFZ is approximately $11 \mathrm{~km}$, reaching at least the base of the upper crust. The modelled geological cross-sections do not show the existence of detachments, as is the case in some transpressionally deformed areas. Geological sequences of very different origin, such as the Duarte Complex and the Tireo Fm, are folded together without the presence of large scale discontinuities at depth.

The details in the geological cross-sections have helped to constrain the shallower parts of the models. The models highlight the large petrophysical hetero- geneities within the different lithologies and trace the depth contacts between the tectonic units delimited in both the geological and the potential field maps. The magnetic field anomalies clearly reflect faults and shear zones, which are not always easily identifiable on the surface. The results of the modelling also suggest that Oligocene folding which affected Tireo Fm has also affected the basement of Duarte Complex and, together with the temperature changes during the emplacement of the Loma Cabrera batholith, might have modified its magnetic character.

In order to estimate the accuracy of our models, we have conducted a series of sensitivity tests. We assume that the uppermost crust is well constrained by the geological cross section, and the densities and magnetic susceptibility have been constrained from the petrophysical data. From these tests, we conclude that base of Duarte Complex and Amina-Maimónupper crust beneath the Cibao basin is determined with an uncertainty of about $\pm 500 \mathrm{~m}$ and the base of Tireo Fm., San Juan and Cibao basins are determined with an uncertainty of $\pm 250 \mathrm{~m}$. It can be established that dips are well traced to depth because the model fits fairly well the short wavelength anomalies and the slopes of the observed magnetic data. Moreover, although the seismic lines presented in Electroconsult (1981) and Mann and Lawrence (1991) lie far from our study area, densities and depths of San Juan and Cibao basins calculated in our models are in agreement with those published (we have estimated the densities of the units imaged by the seismic sections presented there, from the available Pseismic velocities using standard relationships). The depths of these basins obtained from our models are also in agreement with the depths shown in their seismic interpretation.

To assess the uncertainties in the shape and physical properties of the gabbroic rocks, we use the Loma Cabrera Batholith as an example. Variations of the gabbro's susceptibilities were made in order to adjust the magnetic data. There is no a priori information on the depth geometry of the body; its shape is based on the assumption that the gabbro postdates the Tireo Fm and crosscuts that formation and is also a suitable geometry to fit the gravity and magnetic data. Typically, gabbroic-type formations have shapes that range from cylindrical to lopolithic, and these geometries are the ones used in the models (nonetheless, if the intrusions were granitic-type, a laccolithic shape would be more appropriate). As for choosing the gabbro's density, $2.95 \mathrm{Mg} / \mathrm{m}^{3}$ is the density average for gabbros, whereas $2.97 \mathrm{Mg} / \mathrm{m}^{3}$ is its density mode. In this case, only 5 out of 25 samples show this density; moreover, changing from $2.95 \mathrm{Mg} / \mathrm{m}^{3}$ to $2.97 \mathrm{Mg} / \mathrm{m}^{3}$ 
does not change significantly the adjustment (about 2 to $5 \mathrm{mGal}$ ). Therefore, we have preferred to keep the average value. With the actual properties, the uncertainty of the gabbro's base in its central part is about $1 \mathrm{~km}$.

\section{Conclusions}

- The petrophysical analysis from the samples has allowed us to characterize the density and magnetic susceptibility of the main tectonic units of the Dominican Republic, particularly in the Central Cordillera. The studied lithologies show a great variety of density from $2.31 \mathrm{Mg} / \mathrm{m}^{3}$ of the slates to 3.18 $\mathrm{Mg} / \mathrm{m}^{3}$ of the eclogites, magnetic susceptibility from $2 \times 10^{-5} \mathrm{SI}$ of the acid tuffs to $10979 \times 10^{-5} \mathrm{SI}$ of the ultrabasic rocks and remanent magnetization with $\mathrm{Qnm}$ values from 0.07 for the slates to 21.07 for the acid tuffs. Due to the lack of seismic and borehole constraints, petrophysical data has been a fundamental input in the 2.5D models presented in this work.

- Due to the significant variation of magnetite content in the Dominican Republic lithologies, the magnetic field shows remarkable patterns that allow an easy identification of rock types, particularly in the Central Cordillera rocks, and hence the different tectonic domains and structures that form this part of Hispaniola Island. Magnetic interpretation provides a detailed image of the structure and variation of properties across the upper crust in the Central Cordillera.

- Differences in the magnetic fabric can be correlated with different geochemical compositions, suggesting that the different crustal domains in the Central Cordillera were part of different crustal domains of the Cretaceous Caribbean island arc, initially formed apart and later juxtaposed as a result of the transpressive tectonic regime from the Middle Eocene arc-continent collision.

- As a result of the scarce distribution of the gravity data, the mass distribution of the upper crust under the Central Cordillera is mainly constrained by the magnetic data. Magnetic interpretation allows us to infer the structure and properties variation across the upper crust in Central Cordillera. Five domains can be identified from the magnetic data, which are bounded by major fault zones and are correlated to the structural domains. The main tectonic boundary is the HFZ, characterized by a density of $3.0 \mathrm{Mg} / \mathrm{m} 3$ and a magnetic susceptibility of $0.003 \mathrm{SI}$, that separates the Central Cordillera (underlying by Duarte Complex), from the Cibao basin (underlain by Amina Fm.), two domains of different magnetic fabric. The mafic to felsic metavolcanic rocks of the Amina Fm have a differ- ent whole-rock composition, structural fabric and geological history compared to the Duarte Complex. As a consequence, the Duarte Complex is characterized by short wavelength magnetic anomalies, whereas the Cibao basin displays a flat magnetic response. From our modelling results we conclude that the geological cross-sections through the Central Cordillera do not show the existence of detachments, as is the case in some transpressionally deformed areas. In this case, geological sequences of dissimilar origin, such as the Duarte Complex and Tireo Fm, are folded together without the presence of large scale discontinuities at depth.

- Patterns in the Central Cordillera magnetic field are due to the interference between: (1) intermediate to long wavelength anomalies caused by an heterogeneous magnetic basement, Duarte Complex, of bimodal susceptibility, plus the effect of the paramagnetic character of the Cibao and San Juan Basin sedimentary basins (depths up to $6.5 \mathrm{~km}$ ); (2) short wavelength anomalies originated by the lateral variations in magnetic susceptibility of the volcanosedimentary rocks of Tireo Fm and Loma Cabrera batholith intrusive rocks and allied complexes (depths up to 6-8 km).

- The results of the modelling highlight the great petrophysical heterogeneities within the different lithologies crossed by the profile. The models show the possible geometry of the contacts between the tectonic units as well as faults and shear zones in depth. The results of the modelling also suggest that Oligocene folding which affected Tireo $\mathrm{Fm}$ has also affected the basement of the Duarte Complex. The temperature changes during the emplacement of the Loma Cabrera batholith might have modified its magnetic character.

- Given the lack of seismic and borehole data at the Central Cordillera and near our study area, the integration of field petrophysics, geology and potential field analysis and modelling, represents an important methodological aspect of this study. Petrophysical analysis and modelling results together with the analysis of the high resolution aeromagnetic and the available gravity data has contributed to expand our understanding of the whole architecture of the Central Cordillera and its tectonic evolution since Mesozoic times.

\section{Acknowledgements}

This study is a follow up of mapping projects $\mathrm{K}$ and $\mathrm{L}$ financed by SYSMIN program from the European Union. Juliana Martín León, Derek Fairhead and Fernando Bohoyo are thanked for their valuable dis- 
Ayala, C., et al., 2017. High resolution magnetic, regional gravity and petrophysical... Boletín Geológico y Minero, 128 (3): $611-631$

cussions and contributions. Two anonymous referees are thanked for their careful manuscript review and thoughtful comments.

\section{References}

Bowin, C., 1975. The geology of Española, In: Naim, A. Stehli, F. (eds.). The ocean basins and margins: The Gulf of Mexico and the Caribbean, vol. 3. New York, Plenum Press, 501-552.

Contreras, F., 2004. Mapa Geológico de la Hoja Escala 1:50.000 $n^{\circ}$ 5974-II (Monción) y Memoria correspondiente. Proyecto "K" de Cartografía Geotemática de la República Dominicana. Programa SYSMIN. Dirección General de Minería, Santo Domingo.

Compagnie General de Géophysique, 1997. Prospección magnética y radiométrica aeroportada del Territorio de la República Dominicana. Informe Final para la Dirección General de Minería en el marco del Programa SYSMIN (/ACP DO 074). 67 pp., 5 anexos.

Dewey, J. F., Holdsworth, R. E. Y Strachan, R.A., 1998. Transpression and transtension zones. In: Holdsworth, R. E., Strachan, R.A. y Dewey, J. F. (eds.) Continental Transpression and Transtensional Tectonics. Geological Society, London, Special Publication, 135, 41-58.

De Zoeten, R and Mann, P. 1999. Chapter 11 Cenozoic el mamey group of northern hispaniola: a sedimentary record of subduction, collisional and strike-slip events within the north America-Caribbean plate boundary zone. Sedimentary Basins of the World, 4, 247-286.

Díaz de Neira, J. A. and Solé Pont, F. J., 2002. Stratigraphic precisions about the Neogene of the Azua basin (Dominican Republic). Acta Geológica Hispánica, 37 (23), 163-181.

Dolan, J. F., Mann, P., De Zoeten, R., Heubeck, C., Shiroma, J., Monechi, S., 1991. Sedimentologic, stratigraphic, and tectonic synthesis of Eocene-Miocene sedimentary basins, Hispaniola and Puerto Rico. In Mann, P., Draper, G., Lewis, J.F., (eds.). Geologic and Tectonic development of the North America-Caribbean plate boundary in Hispaniola, Geol. Soc. Am. Spec. Paper, 262, 217-263.

Dolan, J. F., Mullins, H. T., David, J. W., 1998. Active tectonics of the north-central Caribbean: Oblique, strain partitioning and opposing subducted slabs. Geological Society of America Special Paper 326, 1-62.

Draper, G. and Lewis, J., 1991. Deformation in the blueschists of the Greater Antilles - Subduction versus collision Processes. Tectonophysics 191 (3-4). 415-416.

Draper G. and Nagle F., 1991. Geology, structure and tectonic development of the Rio San Juan Complex, northern Dominican Republic. In: Mann P, Draper G, Lewis J (eds) Geologic and tectonic development of the North America-Caribbean plate boundary zone in Hispaniola. Geological Society of America Special Papers, 262, 77-95

Draper, G., Gutierrez, G., and Lewis, J., 1996. Thrust emplacement of the Española peridotite belt: Orogenic expression of the Mid Cretaceous Caribbean arc polarity reversal. Geology, 24, 1143-1146.

Electroconsult, 1981. Estudios Geotérmicos de las zonas de Yayas de Viajama-constanza. Dirección General de Minería, B. I. B. 118 pp.

Escuder-Viruete, J., Hernáiz Huerta, P. P., Draper, G., Gutiérrez, G., Lewis, J. F. and Pérez-Estaún, A., 2002. The metamorphism and structure of the Maimón Formation and Duarte and Río Verde Complexes, Dominican Central Cordillera: implications for the structure and evolution of the primitive Caribbean Island Arc. Acta Geológica Hispánica, 37, 123-162.

Escuder-Viruete, J., Pérez Estaún, A., 2004. Trayectoria metamórfica P-T relacionada con subducción en Eclogitas del complejo de basamento de Samaná, Cordillera Septentrional, República Dominicana. Geo-Temas 6 (1): 37-40.

Escuder-Viruete, J., Contreras, F., Stein, G., Urien, P., Joubert, M., Ullrich, T., Mortensen, J. and Pérez-Estaún, A., 2006-a. Transpression and strain partitioning in the Caribbean Island-arc: Fabric development, kinematics and Ar-Ar ages of syntectonic emplacement of the Loma Cabrera batholith, Dominican Republic. Journal of Structural Geology, 28, 1496-1519.

Escuder-Viruete, J., Díaz de Neira, A., Hernáiz Huerta, P. P., Monthel, J., García Senz, J., Joubert, M., Lopera, E., Ullrich, T., Friedman, R., Mortensen, J. and Pérez-Estaún, A., 2006-b. Magmatic relationships and ages of Caribbean Island arc tholeiites, boninites and related felsic rocks, Dominican Republic. Lithos 90, 161-186.

Escuder-Viruete, J. and Pérez-Estaún, A., 2006-c). Subduction-related P-T path for eclogites and garnet glaucophanites from the Samaná Peninsula basement complex, northern Hispaniola. International Journal of Earth Sciences (Geol Rundsch), 95, 995-1017, DOI 10.1007/s00531-006-0079-5.

Escuder-Viruete, J., Contreras, F., Stein, G., Urien, P., Joubert, M., Pérez-Estaún, A., Friedman, R., Ullrich, T., 2007. Magmatic relationships and ages between adakites, magnesian andesites and nb-enriched basaltandesites from Hispaniola: record of a major change in the Caribbean Island arc magma sources. Lithos, 99, 151-177

Escuder-Viruete, J., Joubert, M., Urien, P., Friedman, R., Weis, D., Ullrich, T. and Pérez-Estaún, A., 2008. Caribbean island-arc rifting and back-arc basin development in the Late Cretaceous: Geochemical, isotopic and geochronological evidence from Central Hispaniola. Lithos, 104, 378-404.

Escuder-Viruete J., Pérez-Estaún A., Weis D., 2009. Geochemical constraints on the origin of late Jurassic proto-caribbean oceanic crust in Hispaniola. International Journal of Earth Sciences, 98, 407-425.

García-Lobón, J. L., y Rey-Moral, C., 2002-a. Proyecto “K” de Cartografía Geotemática de la República Dominicana. Programa SYSMIN (7acp do 024). Informe de interpretación de la geofísica aeroportada (magnetismo y radiación gamma natural). 47 pp. Informe IGME G5-003.02. Código 62512.

García-Lobón, J. L., y Rey-Moral, C., 2002-b. Proyecto “L” de 
Ayala, C., et al., 2017. High resolution magnetic, regional gravity and petrophysical... Boletín Geológico y Minero, 128 (3): $611-631$

Cartografía Geotemática de la República Dominicana. Programa SYSMIN (7acp do 024). Informe de interpretación de la geofísica aeroportada (magnetismo y radiación gamma natural). 57 pp. Informe IGME G5-004.02. Código 62513.

García-Lobón, J. L., 2003. Petrofísica e interpretación integrada de datos aeromagnéticos. Aplicaciones a los complejos ígneos del área de Monesterio. Tesis Doctoral. Universidad Politécnica de Madrid. Escuela Técnica Superior de Ingenieros de Minas.

García-Lobón, J. L., y Ayala, C., 2005. Cartografía geofísica de la República Dominicana: Datos de densidad, susceptibilidad magnética y magnetización remanente. IGME Informe num. 62916.

García-Lobón, J. L., y Ayala, C., 2007. Cartografía geofísica de la República Dominicana: Datos de densidad, susceptibilidad magnética y magnetización remanente. Geophysical mapping of the Dominican Republic: density, magnetic susceptibility and remanent magnetisation data. Boletín Geológico y Minero, 118 (2): 175-194.

García-Lobón, J. L., Ayala, C., Rey-Moral, C. y Padín-Debén, A., 2007. Cartografía Geotemática de la República Dominicana: "Proyecto 2007-2010" (con zonas de ampliación). PROGRAMA SYSMIN, 7ACP DO 024, IGME Informe num. 63355 128pp, 54 figures and 70 maps.

Gonçalves P., Guillot S., Lardeaux J. M., Nicollet C. and de Lepinay B. M., 2000. Thrusting and sinistral wrenching in a pre-Eocene HP-LT Caribbean accretionary wedge (Samaná Peninsula, Dominican Republic) Geodinamica acta 13 (2-3), 119-132.

Hernáiz Huerta, P. P., 2000. Programa de Cartografía Geotemática de la República Dominicana. Hojas Escala 1:50.000. Proyecto SYSMIN. Dirección General de Minería, Santo Domingo.

Heubeck, C. and Mann, P., 1988. Cenozoic deformational history of Hispaniola.1. Southeastern Cordillera Central. AAPG Bulletin-American association of petroleum geologists 72 (2), 197-197.

Kerr, A. C.; Tarney, J.; Kempton, P. D.; Spadea, P.; Nivia, A.; Marriner, G. F. and Duncan, R. A., 2002. Pervasive mantle plume head heterogeneity: Evidence from the late Cretaceous Caribbean-Colombian Oceanic Plateau, Journal of Geophysical Research, 107 (B7), DOI 10.1029, $2001 J B 000790$.

Krebs, M.; Maresch, W.V.; Schertl, H.-P.; Baumann, A.; Draper, G; Idleman, B.; Münker, C.; and Trapp, E., 2008. The dynamics of intra-oceanic subduction zones: $A$ direct comparison between fossil petrological evidence (Rio San Juan Complex, Dominican Republic) and numerical simulation. Lithos, v. 103, 106-137

Lewis, J. F. and Draper, G., 1990. Geological and tectonic evolution of the northern Caribbean margin. In $\mathrm{G}$. Dengo, J. E. Case (eds.). The Geology of North America, $\mathrm{H}$, The Caribbean region. Geological Society of America, Colorado, 77-140 pp.

Lewis, J. F. and Jiménez, J. G., 1991. Duarte Complex in the La vega-Jarabacoa-Janico Area, Central Española: Geological and Geochemical Features of the Sea floor During the Early Stages of Arc Evolution. In P. Mann, G. Draper, J.F. Lewis (eds.). Geologic and Tectonic
Development of the North America-Caribbean Plate Boundary in Española Geological Society of America Special Papers, 262, 115-142.

Lewis, J. F., Hames, W. E. and Draper, G., 1999. Late Jurassic oceanic crust and Upper Cretaceous Caribbean plateau picritic basalts exposed in the Duarte igneous complex, Española: A Discussion. Journal of Geology, 107, 505508.

Lewis, J. F., Astacio, V. A., Espaillat, J. and Jiménez, J., 2000. The occurrence of volcanogenic massive sulphide deposits in the Maimón Formation, Dominican Republic: The Cerro de Maimón, Loma pesada and Loma Barbuito deposits. In R. Sherlock, R. Barsch, A. Logan (eds.). VMS deposits of Latin America. Geological Society of Canada Special Publication, 223-249 pp.

Lewis, J. F., Escuder-Viruete, J., Hernaiz Huerta, P. P., Gutiérrez, G., Draper, G. and Pérez-Estaún, A., 2002. Geochemical subdivision of the Circum-Caribbean Island Arc, Dominican Cordillera Central: implications for crustal formation, accretion and growth within an intra-oceanic setting. Acta Geológica Hispánica, 37 ( 23), 81-122.

Mann, P. and Lawrence, R. S., 1991. Petroleum potential of Southern Hispaniola. Journal of Petroleum Geology, 14 (3), 291-308.

Mann, P., Draper, G. and Lewis, J. F. (eds.), 1991. Geologic and tectonic development of the North AmericaCaribbean plate boundary in Hispaniola. Geological Society of America Special Papers 262, 401 pp.

Mann, P., F. W. Taylor, R. L. Edwards, and Ku, T. L., 1995. Actively evolving microplate formation by oblique collision and sideways motion along strike-slip faults: An example from the northeastern Caribbean plate margin, Tectonophysics, 246, 1-69.

Mann, P., 1999. Caribbean Sedimentary Basins: Classification and Tectonic Setting from Jurassic to Present. In: Mann, P., editor, Caribbean Basins, series: Sedimentary Basins of the World, Elsevier Science B.V., Amsterdam, The Netherlands, 4, $699 \mathrm{pp}$.

Mann, P., Calais, E., Ruegg, J-C., DeMets, C., Jansma, P., Y Mattioli, G., 2002. Oblique collision in the northeastern Caribbean from GPS measurements and geological observations. Tectonics, 21, 6, p.1- 26.

Maurrasse, F., Husler, J., Georges, G., Schmitt, R., Damond, P., 1979. Upraised Caribbean sea-floor below acoustic reflector B" and the Southern Peninsula of Haiti. Geologie en Mijnbuow, 8, 71-83.

Montgomery, H., Pessagno, E. A., Lewis, J. F. and Schellekens, J., 1994. Paleogeography of Jurassic fragments in the Caribbean. Tectonics 13 (3), 725-732.

Nagle F., 1974. Blueschist, eclogite, paired metamorphic belts, and the early tectonic history of Hispaniola. Geological Society of America Bulletin 85, 1461-1466

Palmer, H. C., 1979. Geology of the Moncion-Jarabacoa area, Dominican Republic. In B. Lidz, F. Nagle (eds.). Tectonic Focal Point of the North Caribbean; Española. Miami Geological Society, 29-68.

Pérez-Estaún, A., Hernaiz Huerta, P.P., Lopera, E., Joubert, M. y Grupo SISMYN, 2007. Geología de la República 
Dominicana: de la construcción de arco-isla a la colisión arco-continente. En: Pérez-Estaún, A., Hernaiz Huerta, P. P., Lopera, E, y Joubert, M. (eds.), La Geología de la República Dominicana. Boletín Geológico y Minero, 118, 157-174.

Rasmussen, R., and Pedersen, L. B., 1979, End corrections in potential field modeling: Geophysical Prospecting, 27, 749-760.

H.E. Ross, R. J. Blakely and M. D. Zoback, 2006. Testing the use of aeromagnetic data for the determination of Curie depth in California, Geophysics, vol. 17, n. 5

Sen, G.R., Hickey-Vargas, G., Waggoner, Maurrasse F., 1988. Geochemistry of basalts from the Dumisseau Formation, southern Haiti; Implications for the origin of the Caribbean crust. Earth Planetary Science. Letters, 87, 423-437.

Stein, G., Urien, P., Fondeur, L., 2004. Mapa Geológico de la Hoja a E. 1:50.000 $n^{\circ}$ 5974-III (Santiago Rodríguez) y Memoria correspondiente. Proyecto "K" de Cartografía
Geotemática de la República Dominicana. Programa SYSMIN. Dirección General de Minería, Santo Domingo. Talwani, M.,Worzel, J.L., Landisman,M. 1959. Rapid gravity computations for two dimensional bodies with application to the Mendocino submarine fracture zone. Journal of Geophysical Research 64, 49-59.

Talwani, M., Heirtzler, J.R., 1964. Computation of magnetic anomalies caused by two dimensional bodies of arbitrary shape. In: Parks, G.A. (Ed.), Computers in themineral industries, Part 1: Stanford University Publications. Geological Sciences 9, pp. 464-480

Urien, P., Joubert, M., 2004. Mapa Geológico de la Hoja Escala 1:50.000 n 5973-I (Diferencia) y Memoria correspondiente. Proyecto "K" de Cartografía Geotemática de la República Dominicana. Programa SYSMIN. Dirección General de Minería, Santo Domingo.

Won, I.J., Bevis, M., 1987. Computing the gravitational and magnetic anomalies due to a polygon: algorithms and Fortran subroutines. Geophysics 52, 232-238.

Recibido: abril 2015

Revisado: junio 2015

Aceptado: agosto 2015

Publicado: septiembre 2017 
